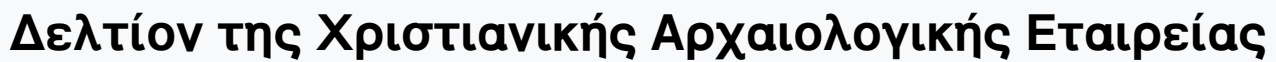

Tó 17 (1994)

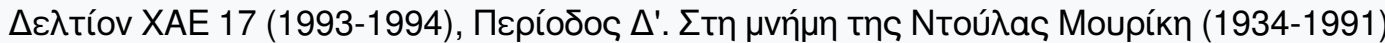

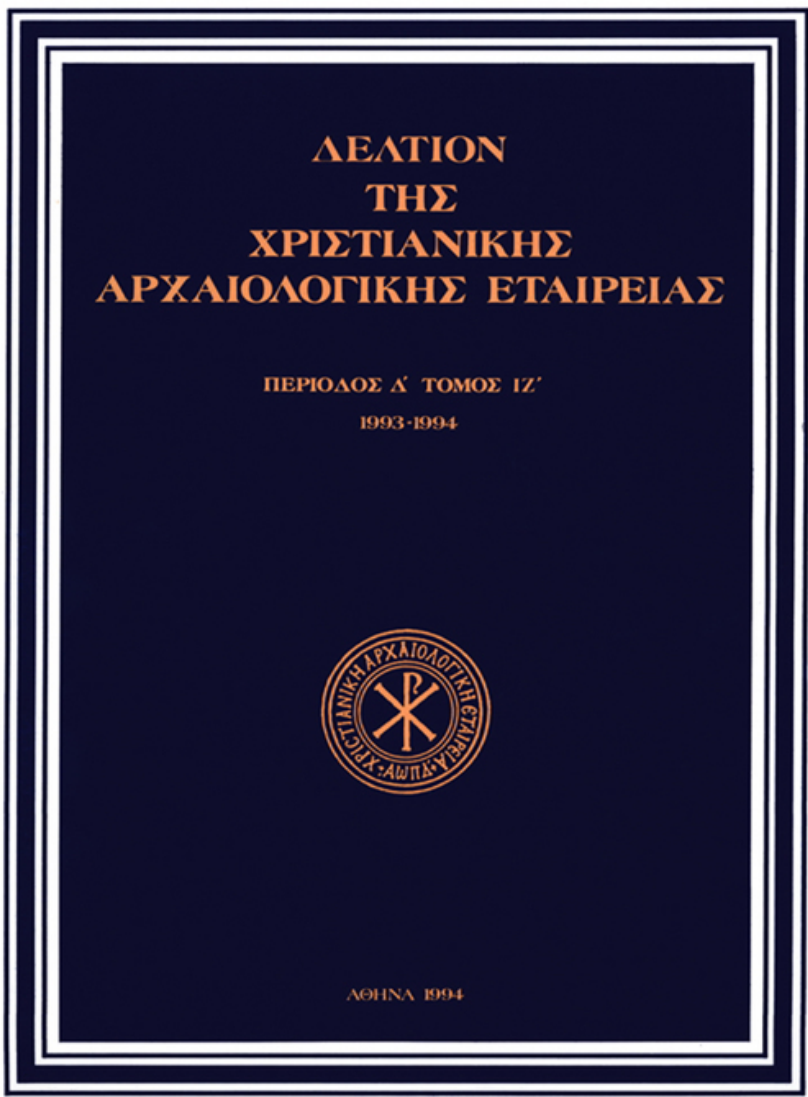

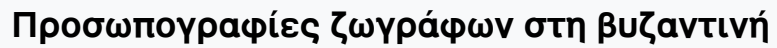
Tغ́XVn

Sophia KALOPISSI-VERTI

doi: $10.12681 /$ dchae.1098

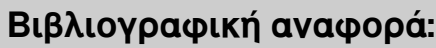

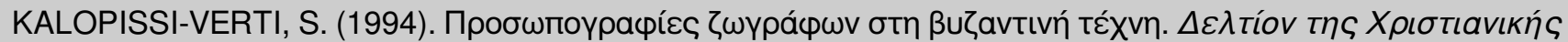

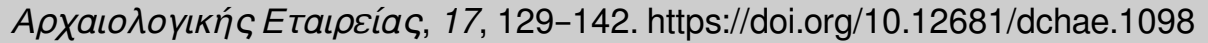




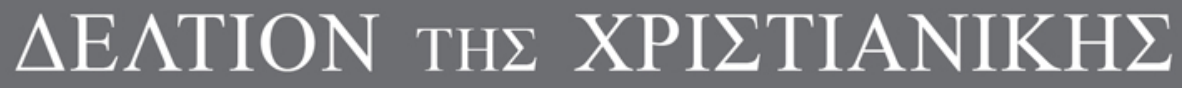 APXAIO $\Lambda$ OГIKH $\Sigma$ ETAIPEIA $\Sigma$}

Painters' Portraits in Byzantine Art

Sophia KALOPISSI-VERTI

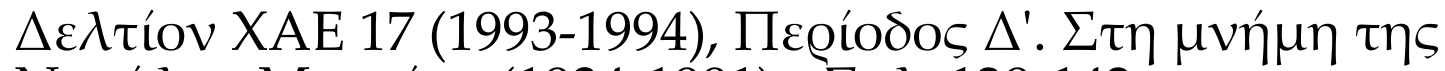

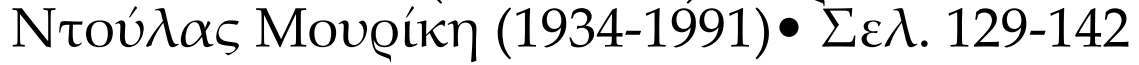

A@HNA 1994 


\section{Sophia Kalopissi-Verti}

\section{PAINTERS' PORTRAITS IN BYZANTINE ART}

$\mathrm{P}$ anonymous. For the authors of the Byzantine ekphraseis, whose references to certain artists of antiquity is a commonplace $^{1}$, names of contemporary masters seem to be, generally speaking, of no importance, although their abilities and competence are highly praised. Likewise, mentions of Byzantine painters' names are rare in poems or epigrams referring to works of $\operatorname{art}^{2}$. Furthermore, dedicatory church inscriptions rarely include their names, which are mostly recorded in short invocations or "signatures" written in quasi indiscernible places of the church ${ }^{3}$. The very secondary role of the painter in comparison to the donor is also evident in the extant portraits. Effigies of donors by far outnumber those of painters ${ }^{4}$. The context of those few extant images of painters in Byzantine art is the subject of the present paper.

The oldest known representation of an image maker in Byzantine art, is found in the codex of Dioscorides in the Austrian National Library in Vienna (Cod. Vindob. Med. gr. 1, f. $5 \mathrm{v})^{5}$. The precious manuscript, which mainly

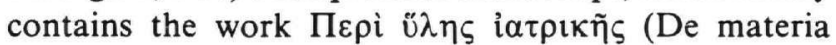
medica) of the Greek physician Dioscorides (1st century AC), was executed in Constantinople shortly before 512 AD and offered in gratitude by the inhabitants of Honoratai to princess Anicia Juliana who had erected a church for them. In the full-page miniature of f. $5 \mathrm{v}^{6}$ (Fig. 1) Dioscorides is depicted recording, in an open book, his observations about the mandragora, a plant of therapeutic-anaesthetic properties, which is held by the personification of Epinoia. On the left side of the miniature, the figure of a seated painter at work goes back to Hellenistic and Roman models ${ }^{7}$ and offers a detailed insight into a painter's atelier and implements in Late Antiquity. Dressed in a short red chiton, tight white breeches and high black boots, the painter turns his head towards his model which he copies on a piece of white parchment nailed to the easel. To his left, on a low bench, there are six shells containing pigments. He
1. For examples see I. Š̀ evčenko, Theodore Metochites, the Chora and the Intellectual Trends of his Time, in: P. Underwood (ed.), The Kariye Djami, IV, Princeton 1975, p. 51, n. 227-229.

2. The most striking examples are the two long poems of Theodore Metochites referring to the Mone Choras, in which the mosaicists are not recorded, M. Treu (ed.), Dichtungen des Groß-Logotheten Theodoros Metochites (Programm des Victoria Gymnasiums zu Potsdam), Potsdam 1895, p. 1-54. For rare references to painters' names in epigrams see E. Kurtz, Die Gedichte des Christophoros Mitylenaios, Leipzig 1903, p. 75, no. 112. E. Miller, Manuelis Philae Carmina, Amsterdam 1967, I, p. 35, 131, 433; II, p. 25. On the subject cf. N. Oi k o n o midès, L'artiste-amateur à Byzance, in: Artistes, artisans et production artistique au moyen âge, Colloque International Rennes 1983, ed. by X. Barral I Altet, I, Les hommes, Paris 1986, p. 46.

3. Sophia Kalopissi-Verti, Painters in Late Byzantine Society. The Evidence of Church Inscriptions, CahArch 42 (1994) (in press). 4. For example, from all portraits treated in I. Spatharakis, The Portrait in Byzantine Illuminated Manuscripts, Leiden 1976 (hereafter: S pa th a r a k is, Portrait) only four belong to painters: Coislin 79, p. $107 \mathrm{ff}$., Melbourne 710/5, p. 76ff., Dionysiou 65, p. 49ff, Par. gr. 36, p. 77 .

5. P. Buberl, Die byzantinischen Handschriften I. Der Wiener Dioskurides und die Wiener Genesis (Beschreibendes Verzeichnis der illuminierten Handschriften in Österreich VIII 4), Leipzig 1937, p. 1-62. Dioscurides Codex Vindobonensis med. gr. 1 der Österreichischen Nationalbibliothek. Facsimileausgabe (Codices Selecti Facsim. vol. XII - Commentarium vol. XII), Graz 1970. H. Hunger, in: RbK 1, Stuttgart 1966, cols. 1191-1196. I. S patharakis, Corpus of Dated Illuminated Greek Manuscripts to the Year 1453, Leiden 1981, p. 5-6, no. 1 (with complete previous bibliography; hereafter: $\mathrm{Spath}$ a ra k is, Corpus).

6. Buberl, op.cit., p. 26ff., pl. V. H. Gerstinger, Kommentarband zu der Facsimileausgabe, Graz 1970, p. 32-33. K. Weit z m a n n, The Classical in Byzantine Art as a Mode of Individual Expression, in: Byzantine Art - An European Art, Lectures, Athens 1966, p. 160, fig. 122 (= K. Weitzma n n, Studies in Classical and Byzantine Manuscript Illumination, ed. by H. L. Kessler, Chicago - London 1971, p. 159, fig. 136) (hereafter: Studies).

7. Gerstinger, op.cit., p. 33,57 , n. 82 , fig. 35 . On the antique prototypes of the illuminations of the Codex of Dioscorides see P. B u be r l, Die antiken Grundlagen der Miniaturen des Wiener Dioskurideskodex, JdI 51 (1936), p. 114-136; B. Sch we it zer, Zum antiken Künstlerbild, Corolla Ludwig Curtius zum sechzigsten Geburtstag dargebracht, Stuttgart 1937, p. 35-44, pls 2-3. Cf. K. Weit z ma n n, The Classical Heritage in the Art of Constantinople, in: Studies, p. 135ff.; id., The Classical in Byzantine Art, in: Byzantine Art - An European Art, op.cit., p. 160ff. and in: Studies, p. 154ff. 
holds a brush in his right hand and a small pigment vessel in his left. Although there are inscriptions naming Dioscorides and Epinoia, this excellent illuminator of Late Antiquity remains anonymous. However, despite his anonymity, the image maker of the codex of Vienna represents the concrete painter of the archetype and is rendered in a realistic way.

The majority of the extant examples of Byzantine painters' portraits belong to the period extending from the early 9th century to about 1200 . Two effigies of painters at work, dating to the 9 th and 11 th century respectively, demonstrate a typically medieval approach to the subject. The first image is found in the margin of f. $328 \mathrm{v}$ of the codex of John Damascenus' Sacra Parallela in Paris (Bibliothèque Nationale, Cod. Par. gr. 923) ${ }^{8}$ (Fig. 2). This codex goes back, according to Weitzmann, to the first half of the 9th century, i.e. to the Late Iconoclastic period, and must have been produced in the monastery of Saint Sabas in Palestine?.

The painter is depicted seated, copying an icon which represents the bust of a figure on a board resting on his knee. He paints with a brush held in his right hand. The rendering of the miniature is limited to the essentials. The icon used as a model seems to sway in front of the painter, as it is neither fixed on the wall nor set on an easel. There is no nimbus around the holy figure of the icon and, with the exception of the faces and the painter's hand, everything is rendered in gold.

The marginal miniature does not represent the actual painter of the book. It depicts a painter in abstracto as it illustrates a metaphor included in the text of the second epistle of Saint Basil the Great ${ }^{10}$ which is comprised in

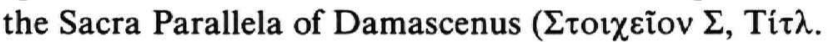

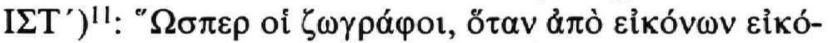

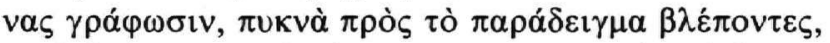

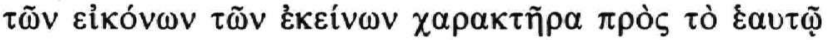

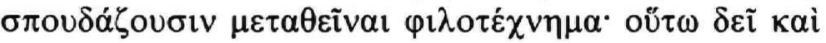

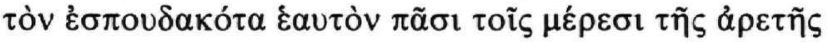

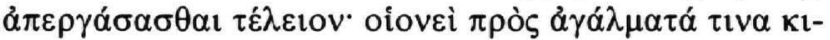

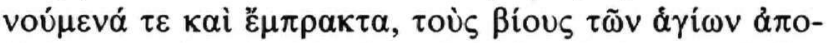

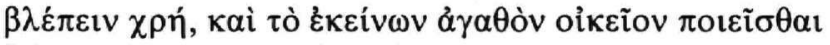
$\delta ı \grave{\alpha} \mu \iota \mu \eta \dot{\sigma} \sigma \omega \varsigma$. "As the painters when they paint icons from icons, looking closely at the model, are eager to transfer the character of the icon to their own masterpiece, so must he who strives to perfect himself in all branches of virtue look at the lives of the saints as if to living and moving images and make their virtue his own by imitation" 12 .

The second painter's portrait is depicted on the margin of $\mathrm{f} .35 \mathrm{r}$ of the Codex 61 of the Dionysiou Monastery on Mount Athos ${ }^{13}$ (Fig. 3). The manuscript includes sixteen homilies of Gregory Nazianzenus which are read during

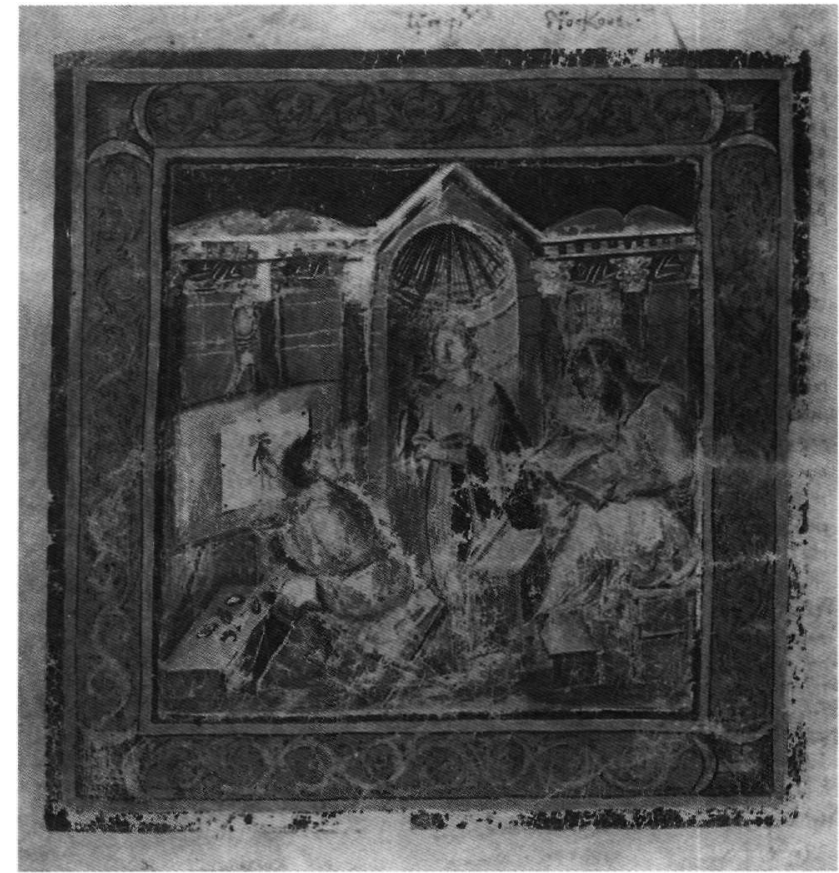

Fig. 1. Vienna, Österreichische Nationalbibliothek, Vindob. Med. gr. 1, f. 5v. Dioscorides, Epinoia and the painter.

Fig. 2. Paris, Bibliothèque Nationale, Par. gr. 923, f. 328v. Marginal miniature of a painter.

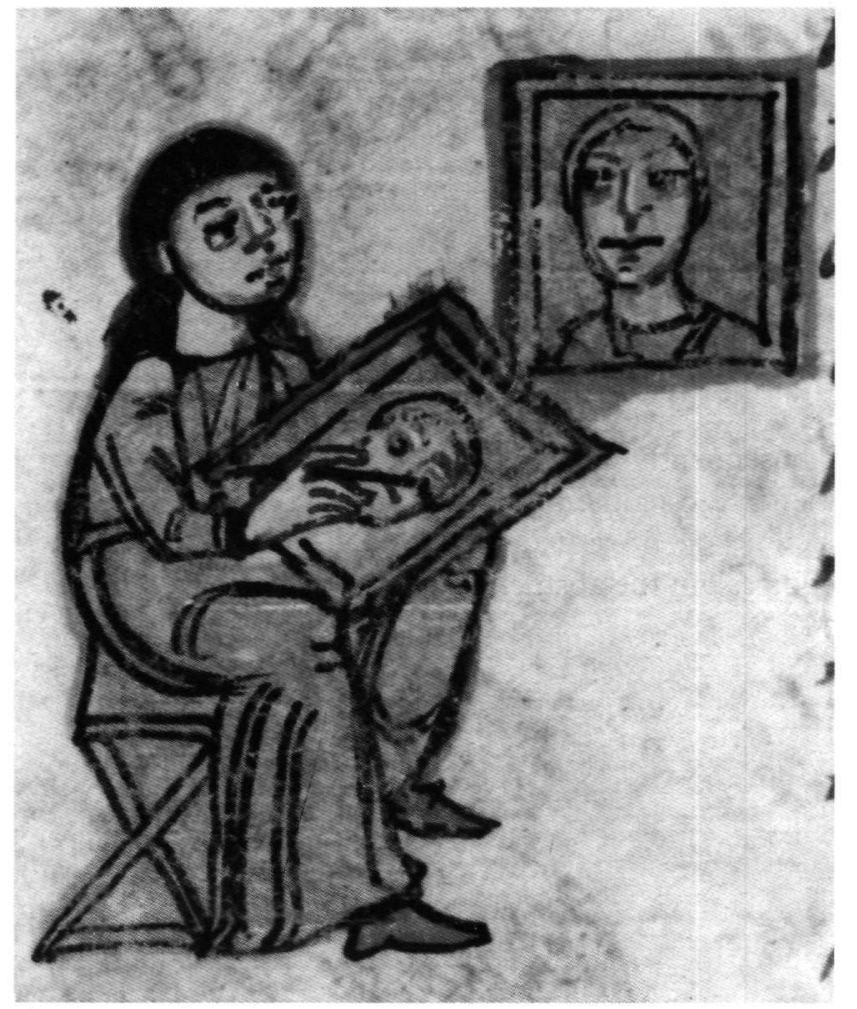


the liturgy and is dated to the second half of the 11 th century $^{14}$. The painter's image is part of the illustration of the beginning of the ninth homily which is a funerary sermon for Saint Basil ${ }^{15}$. The miniature on top of the page illustrates the Koimesis of Saint Basil. Underneath, on the left, the minute figure of Gregory, forms the initial E. He stretches his right hand in which he holds a pen and seems to write the text and at the same time to point to a small figure of a painter depicted in the right margin. The painter, seated on a stool with a cushion, although very small in dimensions, is rendered with many details. He has brown hair, a short beard and is dressed in a simple, long red garment with long sleeves. On his head he wears a white headcover. In his raised right hand he holds a brush with which he is painting an icon set on an easel which rests upon four legs. The figure painted on the icon seems to represent Gregory, the author of the homily. To the right of the painter, a low table-like piece of furniture with a closed twoleaved door is depicted, similar to those very often illustrated in representations of evangelists. The whole picture is so minute that no pigments, brushes or other implements can be discerned.

As in the previous example, the painter's effigy in Dionysiou 61 does not depict the concrete illuminator of the manuscript. It rather has a symbolical-abstract meaning as it illustrates a metaphor used in the homily of Gre-

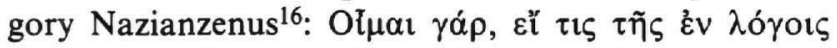

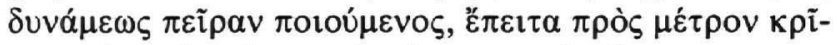

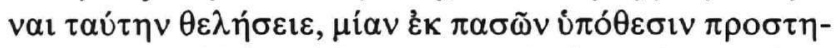

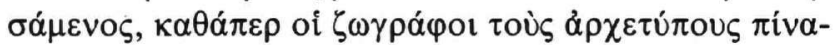

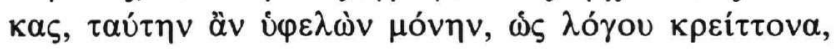

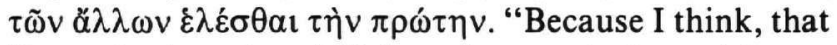
if somebody trying skilfulness in speech, then wishes to judge it according to the rule, choosing one assumption among all others, as painters do with the icons they use as archetypes, keeping only this apart, because it is better than speech, he will prefer the first to the others". Consequently, echoing medieval concepts, both aforementioned painters' effigies, in Par. gr. 923 and in Dionysiou 61 , do not depict the real miniaturists of the codices but the abstract idea of the painter and are used to illustrate literary metaphors included in the texts. Notwithstanding this fact, these portraits may, in my opinion, be considered as a personal intervention of the illuminators, as a sort of an "anonymous signature", since only exceptionally might one of the extant copies of the same work include the painter's portrait.

Moreover, in accordance with medieval concepts about artisans is the idea of depicting a biblical rather than a contemporary painter at work. There are, therefore, rare representations of Saint Luke - who was later, in

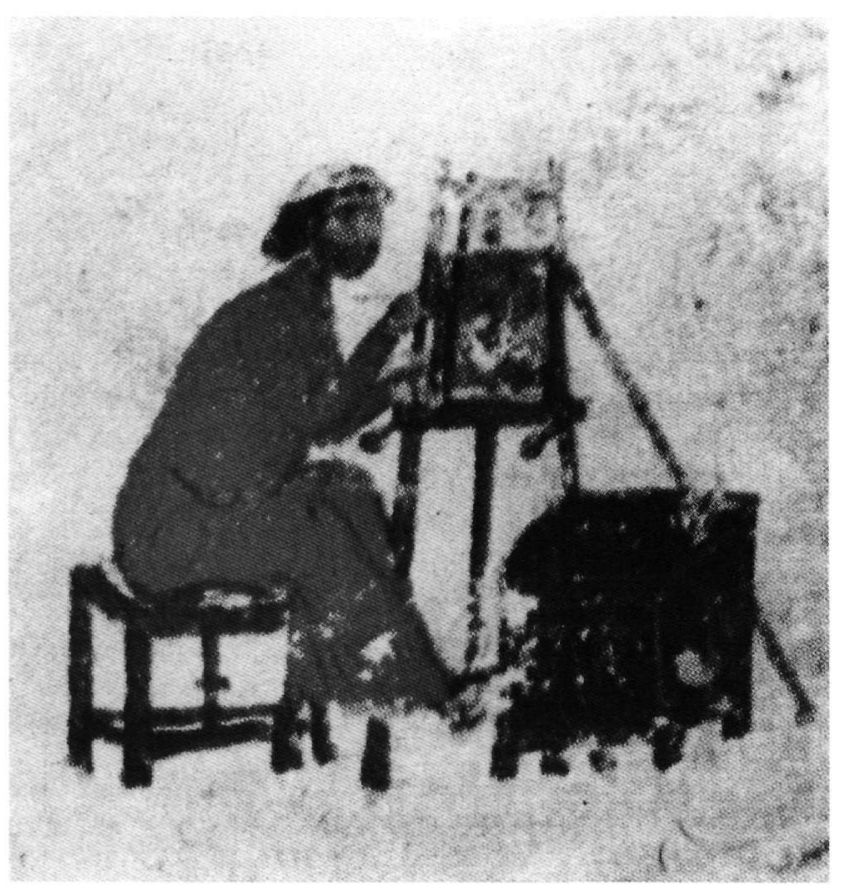

Fig. 3. Athos, Dionysiou 61, f. 35r. Marginal miniature of a painter.

8. K. Weitzmann, The Miniatures of the Sacra Parallela. Parisinus graecus 923 (Studies in Manuscript Illumination 8), Princeton, N.J. 1979, p. 213, pl. CXXVI, fig. 569. Cf. A. Kazhdan - H. Maguire, Byzantine Hagiographical Texts as Sources on Art, DOP 45 (1991), p. 6 , fig. 11.

9. Weitzmann, The Miniatures of the Sacra Parallela, op.cit., p. 23-25.

10. PG 32, col. 229A.

11. Ibid. 96 , col. 352B.

12. Translated by We it z m a n n, The Miniatures of the Sacra Parallela, op.cit., p. 213.

13. G. Galavaris, The Illustrations of the Liturgical Homilies of Gregory Nazianzenus (Studies in Manuscript Illumination 6), Princeton, N.J. 1969, p. 175, 206, fig. 363 (hereafter: Gregory Nazianzenus). St. Pelekanidis - P. Christou - Chrysanthi Mavro-

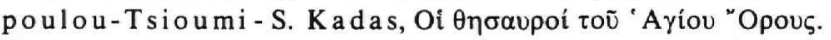

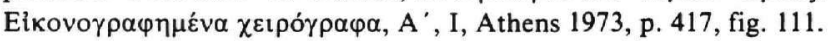
14. On the different views about the dating of the manuscript see Spatharakis, Portrait, p. 119-120.

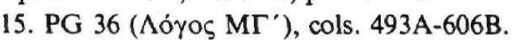

16. Ibid., col. $493 \mathrm{~A}$.

17. Maria Constantoudaki, Dominicos Théotocopoulos (El

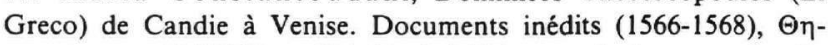

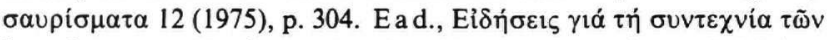

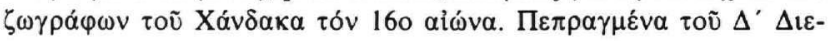

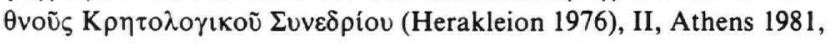
p. 130. J. O. S ch a e fer, Saint Luke as Painter: from Saint to Artisan to Artist, in: Artistes, artisans et production artistique (see above note 2), I, p. 413-420. 


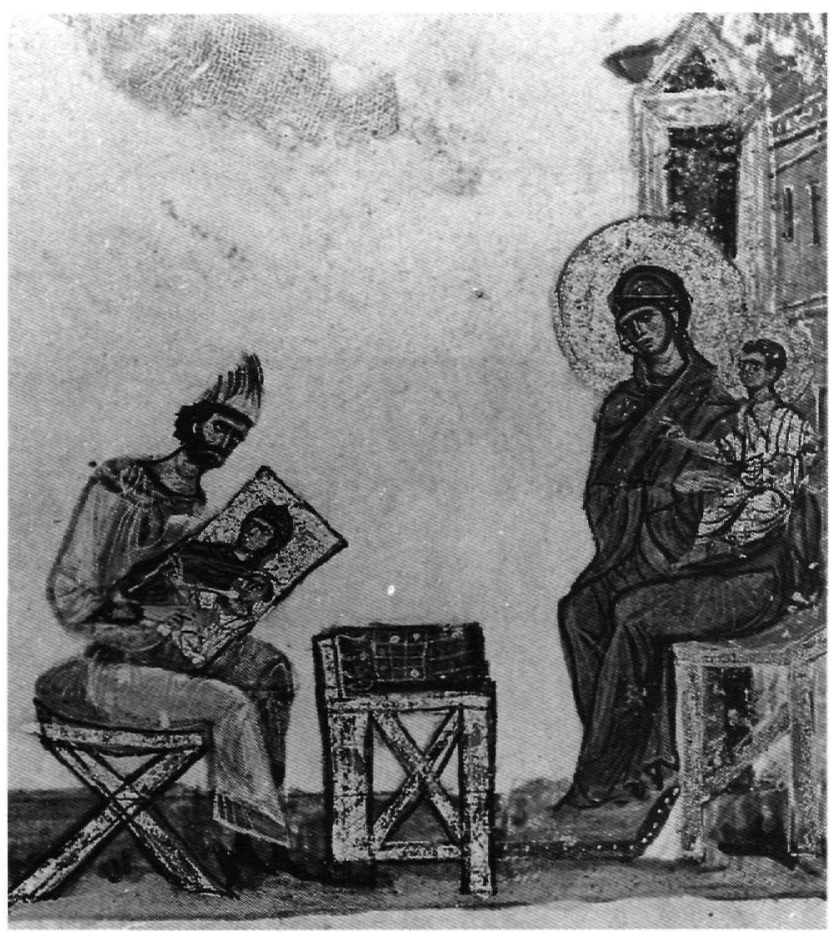

Fig. 4. Jerusalem, Greek Patriarchal Library, Taphou 14, f. 106v. Saint Luke painting the icon of the Virgin.

the 15th and 16th centuries, adopted by the guilds of painters, both in the East and in the West ${ }^{17}$, as their patron saint - showing him painting the Virgin. They are rendered with such accuracy, as for example on $f$. 106v of the codex Taphou 14 in the Greek Patriarchal Library of Jerusalem ${ }^{18}$ (second half of the 11 th century) (Fig. 4), that a good insight is offered into the methods of a medieval painter, the tools of his trade - easel, brushes, paint box, pigment shells - and his use of a model, an essential prerequisite in order to achieve a perfect likeness ${ }^{19}$.

The only case of a portrait of a real and specific painter, in the period under discussion, may be considered the one included in codex Coislin 79 of the National Library in Paris ${ }^{20}$. The well known manuscript comprises a collection of homilies of John Chrysostom and is dated to the eighth decade of the 11th century ${ }^{21}$. As Spatharakis ${ }^{22}$ has shown, the book was originally destined for the Emperor Michael VII Ducas (1071-1078). His portrait was depicted three times - on f. 1 (2bis) v, $2 \mathrm{r}$ and $2 \mathrm{v}-$ and was later retouched to resemble the features of Nicephorus III Botaneiates (1078-1081), who was the final recipient of the codex.

On f. $2 \mathrm{v}$, next to the suppedion of the Emperor Nicephorus III Botaneiates, who is represented between
John Chrysostom and the archangel Michael, a tiny kneeling figure is discernible ${ }^{23}$ (Figs 5-6). He is beardless, i.e. he is a eunuch, and is clad in a red chiton and a blue chlamys. The marginal inscription above the miniature, in perfectly spelt dodecasyllabic verses, reads: 'E

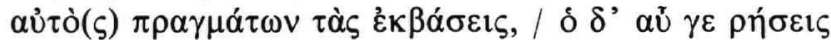

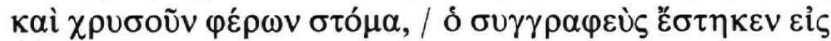

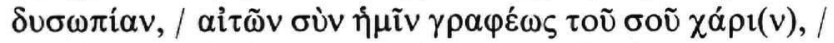

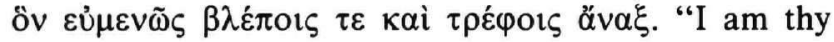
guardian, o bearer of the crown, as I myself know the issue of the events and he who disposes of utterance and of a golden mouth, the author, stands in supplication requesting with us thy grace for thy painter (or scribe), on whom thou mayest look with favour and support him, o King". It should be noted that the word $\gamma \rho \alpha \varphi \varepsilon v \dot{ } \varsigma$ can mean either scribe or painter, but if we accept $\mathrm{Du}$ mitrescu's reasonable argumentation, which will be discussed presently, the small figure should rather be identified with the painter of the sumptuous miniatures than with the scribe of the codex ${ }^{24}$.

Another allusion to the scribe ( $\tau \tilde{\varphi} \gamma \rho \alpha \dot{\varphi} \varphi o v \tau \imath$ ) is found in the marginal inscription of $f$. $2 r$ where the emperor is shown enthroned among the personification of two Virtues, Truth and Justice, and four high officials. The courtier who occupies the place of honour just to the right of the emperor, inscribed as $\delta \alpha^{\prime} \pi \rho \omega \tau$ - $\pi \rho$ ó $\varepsilon \delta \rho \varsigma$

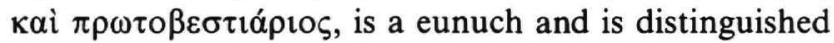
from the other three officials by his costume which alludes to a double function, that of ecclesiastic and that of court official ${ }^{25}$. The marginal inscription above the miniature ends with the lines: $\Pi \lambda \eta \dot{\eta} v \tau \tilde{\varphi} \gamma \rho \alpha \dot{\varphi} \varphi v \tau \imath \sigma u \mu-$

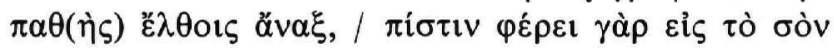

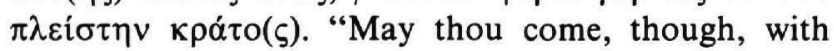
sympathy for the scribe, o King, for he bears absolute loyalty to thy sovereignty".

Dumitrescu argues that the protoproedros should be identified with Ioannes, Metropolitan of Side, whom, she considers as the first ktetor of the manuscript destined as a present for Michael VII Ducas ${ }^{26}$. Certain iconographic details and the emphasis in the marginal inscription of $\mathrm{f}$. $2 \mathrm{r}$ on "him who writes" ( $\tau \tilde{\omega} \gamma \rho \alpha \dot{\varphi} \varphi o v \tau \mathrm{l}$ ), who is most loyal, seem, with good reason, to indicate that the ktetor was also the scribe of the manuscript. Furthermore, Dumitrescu remarks, basing herself on close ad hoc observation, that there is no physiognomical resemblance whatsoever between the protoproedros of $\mathrm{f} .2 \mathrm{r}$ and the tiny figure of f. $2 \mathrm{v}$ (Fig. 6), a fact that eliminates the possibility of identifying the two figures. This argues in favour of the interpretation of the word $\gamma \rho \alpha \varphi \varepsilon v \dot{s}$ of $\mathrm{f} .2 \mathrm{v}$ as painter and not as scribe ${ }^{27}$. If this assumption proves to be true, then the Coislin 79 offers 


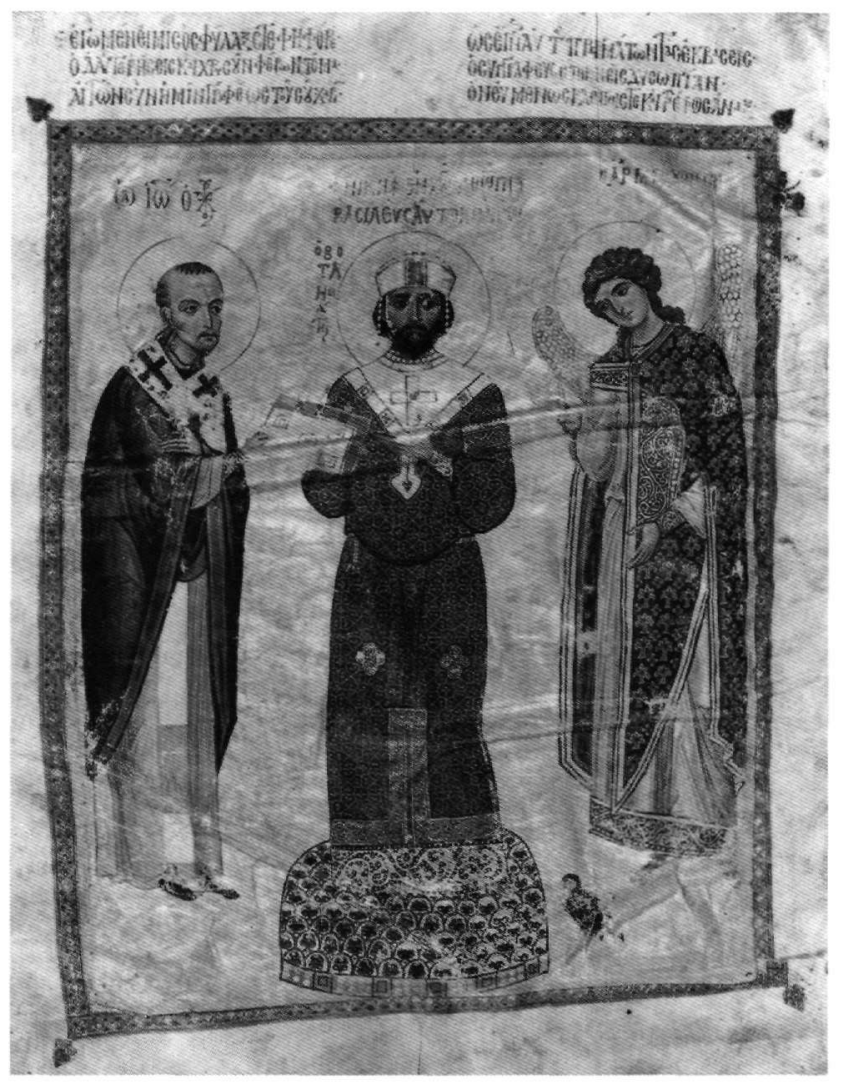

a unique Middle Byzantine example of a self-image of a real miniaturist, depicted exclusively in his function as a painter.

A different approach is demonstrated, on the contrary, by a group of painters' self-images, all sharing a common character, which will be discussed below. In the Melbourne Gospel Book (Cod. 710/5 of the National Gallery of Victoria) dated to about 1100 , on $\mathrm{f} .1 \mathrm{v}$, there is a representation of the Virgin and Child and of a monk who is offering her a codex ${ }^{28}$ (Fig. 7). Both figures are depicted on the same scale, standing under a double arch which carries a triangular roof crowned with a cross. According to the usual iconographic scheme, Christ, seated in His mother's lap, blesses the monk. An

18. Gala va ris, Gregory Nazianzenus, p. 175, 222-226 (with bibliography), esp. 224.

19. On information about painters at work drawn from the hagiographical texts - use of a real person or a picture as a model, preliminary drawing or sketch, colouring etc. - see Kazhdan-Maguire, Byzantine Hagiographical Text (see note 8), p. 1-22. On the likeness with the model see recently G. D a gr o n, Holy Images and Likeness, DOP 45 (1991), p. 23ff.

20. S p at ha ra kis, Portrait, p. 107-118. Id., Corpus, I, p. 30-31, no.

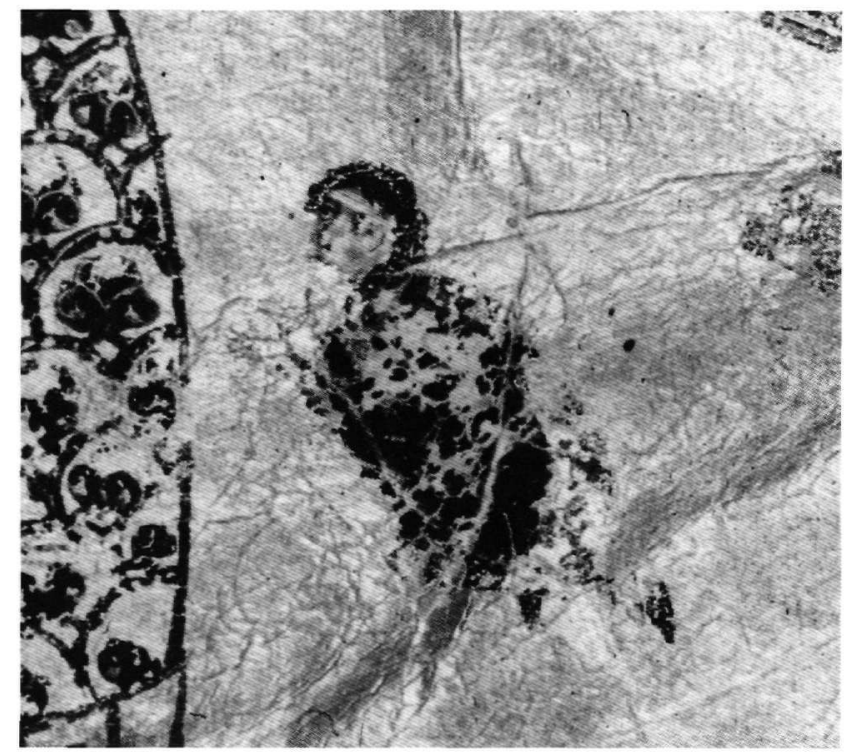

Fig. 5. Paris, Bibliothèque Nationale, Coislin 79, f. 2v. The Emperor Nicephorus III Botaneiates between John Chrysostom and the archangel Michael, and kneeling painter (?).

Fig. 6. Paris, Bibliothèque Nationale, Coislin 79, f. 2v. Painter (?) kneeling at the feet of the Emperor Nicephorus III Botaneiates.

94 (with complete bibliography). Carmen-Laura Dumitrescu, Remarques en marge du Coislin 79: les trois eunuques et le problème du donateur, Byzantion 57 (1987), p. 43-45.

21. S path a rakis, Portrait, p. $107 \mathrm{ff}$. and id., Corpus, p. 30, suggests that the codex was executed between 1074-78. Dumitrescu, op.cit., p. 32ff., dates the first phase of the codex destined for Michael VII Ducas to the year 1071/72 and its second phase made for Nicephorus III Botaneiates to the year $1978 / 79$.

22. S path a ra kis, Portrait, p. 107-118, Id., Portrait Falsifications in Byzantine Illuminated Manuscripts, Actes du XVe Congrès International d'études byzantines, Athènes 1976, Communications IIB, Athens 1981, p. 728-731, fig. 8.

23. Spatharakis, Portrait, fig. 72. Id., Corpus, fig. 174. Dumitrescu, op.cit., fig. 4.

24. Dumitrescu, op.cit., p. 40ff. Already H. Bordie r, Description des peintures et autres ornements dans les manuscrits grecs de la Bibliothèque Nationale, Paris 1883, p. 128-132, esp. 131, fig. 64, identified the prostrate figure at the feet of the emperor with the painter of the miniatures, cf. J. E ber s ol t, La miniature byzantine, Paris-Bruxelles 1926, p. 38, pl. XXXII. A. Cutler - J. Nes bit t, L'arte bizantina e il suo pubblico, Torino 1986, p. 235-236.

25. S patharakis, Portrait, p. 110 ff., fig. 71 . Id., Corpus, p. 30, fig. 173. Dumitrescu, op.cit., p. $39 f f .$, fig. 3.

26. Dumitrescu, op.cit., p. $39 \mathrm{ff}$.

27. Ibid., p. 42.

28. H. Buchtal, An Illuminated Byzantine Gospel Book of about 1100 A.D. Special Bulletin of the National Gallery of Victoria, Centenary Year, Melbourne 1961. S pat ha rakis, Portrait, p. 76-78, fig. 43. For a colour plate see Cutler - Nesbitt, op.cit., p. 237. 
epigram above the miniature, consisting of four dodecasyllabic verses, written in minuscules, runs: "Av $\alpha \sigma \sigma \alpha$

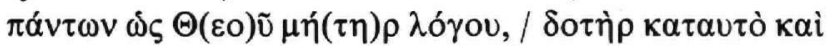

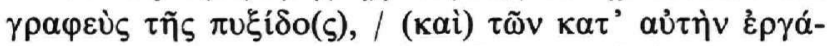

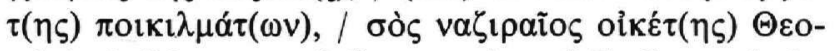
$\varphi \alpha ́ v(\eta \varsigma)$. "O queen of all, as mother of God's word, the donor and at the same time scribe of the book and painter of its ornaments (is) thy servant, the monk Theophanes".

The verses inform us, therefore, that the monk depicted, named Theophanes, is at the same time donor and scribe and painter of the codex and probably also author of the epigram ${ }^{29}$. The fact that Theophanes is depicted in a standing position, on the same scale as the Virgin and bearing a nimbus, reveals a certain pride and indicates, in my opinion, that he is mainly depicted in his capacity as donor of the book, and not as its humble painter.

A parallel example is to be found in the Psalter Dionysiou 65 on Mount Athos ${ }^{30}$, part of which, including the full-page miniatures, may be dated to the first half of the 12 th century ${ }^{31}$. On f. $12 \mathrm{v}$ a prostrate monk is depicted at the feet of the standing Theotokos who holds the Child; the Virgin points to him with her right hand and Christ blesses him (Fig. 8). An inscription under the miniature

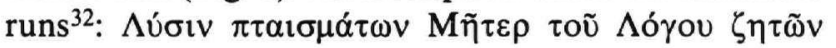

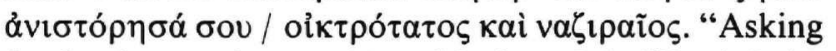
for forgiveness for my sins, o Mother of the Word, I, the most pitiful monk, have illuminated for thee".

The iconographic scheme of the miniature and the phraseology of the inscription $-\lambda v$ vıv $\pi \tau \alpha \iota \sigma \mu \alpha \dot{\tau} \omega \nu \zeta \eta$ $\tau \tilde{\omega} \nu$ - are typical of patron portraiture. Furthermore,

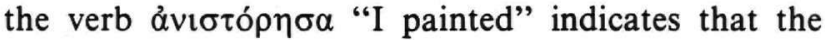
monk was very probably also the illuminator of the codex, although the meaning "I payed for the illumina-

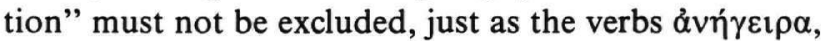

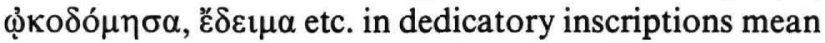
"I payed for the erection" of the church ${ }^{33}$.

Sabas, the name of the monk, his place of origin near Nicomedia and the explicit information that he wrote

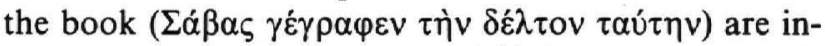
cluded in the colophon on f. $244 \mathrm{r}^{34}$. Sabas was, accordingly, the scribe. Nevertheless, not all the text of the codex is written by him. According to Spatharakis, the manuscript is an amalgam of two different psalters ${ }^{35}$. The part assigned to Sabas (the introduction, the inserted f. 202 and the appendix) is the part of the codex including the eight full-page miniatures, a fact that seems to corroborate the assumption that Sabas was not only the scribe but also the illuminator of the psalter. To conclude, the context of the dedicatory miniature and its inscription, the appearance of Sabas' name once more on $\mathrm{f} .244 \mathrm{v}$ in a cruciform ornament, as well as the information provided by the colophon, support the view that the monk Sabas of Dionysiou 65 was, like the monk Theophanes of the Gospel of Melbourne, not only scribe and illuminator ${ }^{36}$ but also ktetor of the codex ${ }^{37}$. This last quality of his explains the emphatic accentuation of his personality in picture and word.

Another example of a monk, without self-portrait though, who was at the same time ktetor, scribe and illuminator, is recorded in a poem included in a Georgian Menologium executed in Constantinople in the year 1030 (Tbilisi, Gosudarstvennyj Musej Gruzii MS. A 648,

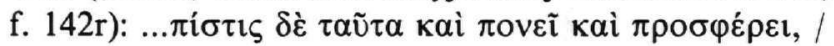

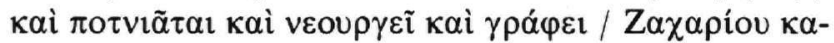
$\lambda$ ○үท́ Zacharias the Georgian executed, offered, restored and wrote all this" 38 .

Of special interest for our investigation is an hexaptychon in the monastery of Saint Catherine at Sinai dated to the second half of the $11 \mathrm{th}^{39}$ or first half of the 12th century ${ }^{40}$. The four side-leaves comprise illustrations of a complete menologion for the whole year. One of the two main panels represents the Last Judgement. On the other main panel there are Christological scenes arranged in four rows and, in the uppermost zone, four copies of miraculous icons of the Virgin, known to have existed in the sanctuaries of Constantinople, are depicted on both sides of the Virgin enthroned.

Greek metric inscriptions ${ }^{41}$ in dodecasyllabic verses on the rear of the icon furnish detailed information about the painter and donor and his intentions. The inscription running along the rear of the four side-panels which bear the illustrations of the menologion informs us that the painter Ioannes depicted the martyrs and the other holy persons in order to have them as mediators before

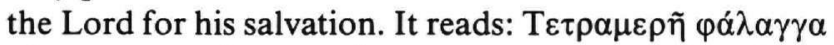

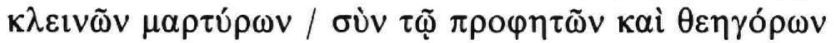

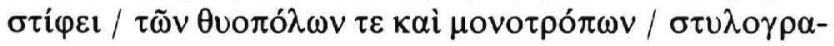

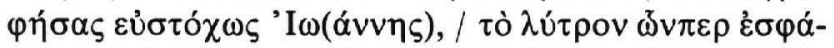

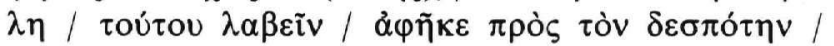
$\pi \rho \varepsilon ́ \sigma \beta \varepsilon เ \varsigma \tau \alpha \chi \varepsilon i \tilde{\varsigma}$. "Having successfully painted a fourpart columm of celebrated martyrs together with a host of prophets and theologians, of priests and monks, Ioannes committed (them) to the ruler as prompt mediators in order to receive redemption from his sins". The first inscription on the rear of the main panel illustrating the five images of the Virgin and the Christological scenes, includes an appeal to the grace and motherly intervention of the Theotokos whose pictures Ioannes

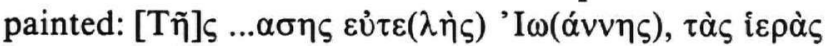

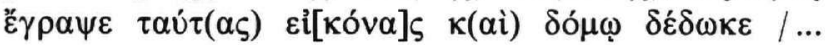

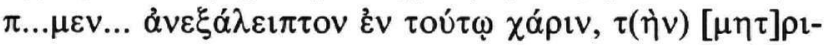




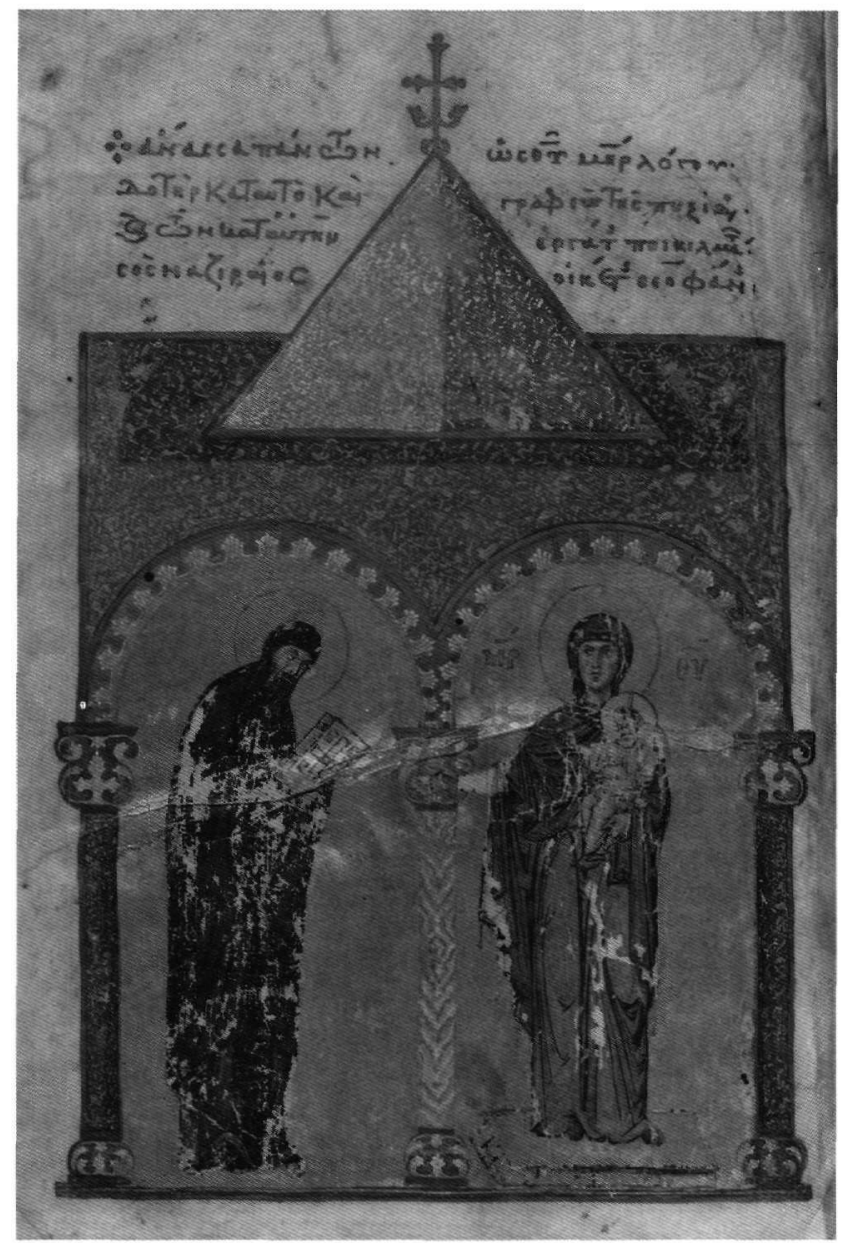

Fig. 7. Melbourne, National Gallery of Victoria, cod. 710/5 (Felton Bequest 1959), f. 1v. The Virgin and the monk Theophanes, donor, scribe and painter.

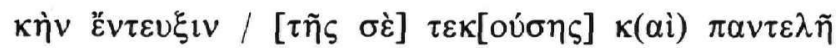

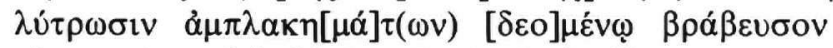

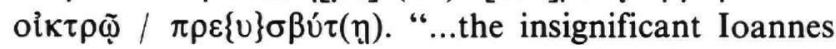
has painted these holy icons and has given them to the church (?) ... (asking that be transformed) into inexhaustible grace the motherly intervention of her who gave birth to thee; and reward the miserable old man who is asking for complete salvation from his sins". In

29. For another example of a miniaturist, the thirteenth-century painter Theoktistos, who also wrote a metric epigram for a miniature of John Chrysostom, see Prosopographisches Lexikon der Palaiologenzeit, ed. by E. Trapp, 4. Faszikel, Vienna 1980, p. 49, no. 7491.

30. Pelekanidis et al, Oi Onoaupoí toũ "A yíou "Opous (see note 13), I, p. 419-421, figs 118-128. Chrysanthi Mavropoulou-

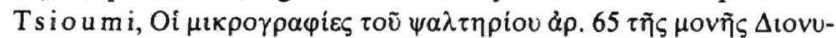

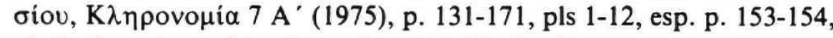
pl. 8. Spatharakis, Portrait, p. 49-51, fig. 18.
31. I. Spatharakis, The Date of the Illustrations of the Psalter Dionysiu 65, $\triangle$ XAE $\Delta^{\prime}, H^{\prime}$ (1975-76), p. 173-177. Id., Portrait, p. 49-50. On the contrary Mavropoulou-Tsioumi, op.cit., p. 135, 169 , on the basis of the Paschal Tables, dates the codex to about 1313 and considers it as a fourteenth-century copy of a manuscript of the 11 th or of the beginning of the 12 th century. Cf. V. La za rev, Storia della pittura bizantina, Torino 1967, p. 422, n. 113. Pelekanidis et

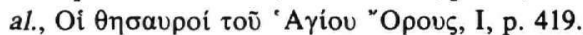

32. S. Lambros, Catalogue of the Greek Manuscripts on Mount Athos, I, Cambridge 1895, p. 325, no. 3599. Mavropoulou-Tsioumi, op.cit., p. 140. Spatharakis, Portrait, p. 51.

33. In an inscription of the 15th century(?) on a fresco-icon of Saint George in the homonymous church in the castle of Geraki, the verb avı $\sigma \tau \rho \rho \tilde{\omega}$ is undoubtedly used with the meaning of "I have payed for the painting", as it refers to the donor, the $\sigma \varepsilon \beta \alpha \sigma \tau \delta \varsigma \tau \zeta \alpha$ ov $\sigma 10 \zeta$ 'I бaákıos, D. Feissel-A. Philippidis-Braat, Inventaires en vue d'un recueil des inscriptions historiques de Byzance. III. Inscriptions du Péloponnèse (à l'exception de Mistra), TM 9 (1985), p. 345, no. 83 .

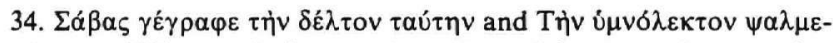

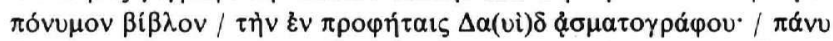

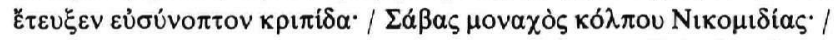

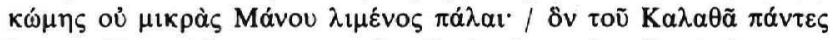

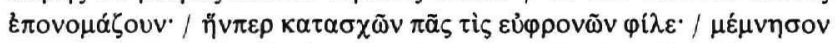

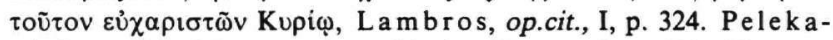

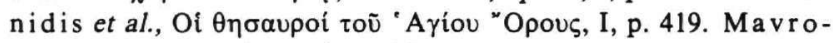
poulou-Tsioumi, op.cit., p. 134.

35. Spatharakis, The Date of the Illustrations, op.cit. (see note 31), p. 176. Id., Portrait, p. 50. On the contrary MavropoulouTs i o u mi, op.cit. (see note 30), p. 134, assigns both main scripts to the same scribe.

36. A celebrated scribe and miniaturist (but not donor) was Theodore, monk of the monastery of Studios, who wrote and illuminated the Psalter British Museum Add. 19.352 in 1066 for Michael, abbot of the same monastery, Sirarpie Der Nersessian, L'illustration des psautiers grecs du Moyen Age, II, Londres, Add. 19.352 (Bibliothèque des CahArch V), Paris 1970, p. 12. On further examples of scribes and illuminators see R. S. Nelson, Theodore Hagiopetrites. A Late Byzantine Scribe and Illuminator (Österreichische Akademie der Wissenschaften. Veröffentlichungen der Kommission für Byzantinistik IV), Vienna 1991, I, p. 38ff., 119-120. For scribes and illuminators and their representations in Medieval Western Europe, esp. in England, see J. J. G. Alexander, Scribes as Artists: the Arabesque Initial in Twelfth-Century English Manuscripts, in: Medieval Scribes, Manuscripts and Libraries. Essays Presented to N. R. Ker (ed. by M. B. Parkes and A. G. Watson), London 1978, p. 87-116, esp. $107 \mathrm{ff}$.

37. Spatharakis, Portrait, p. 51, 77-78. Cf. MavropoulouTs i o u mi, op.cit. (see note 30), p. 169.

38. Text and translation in I. Sevcenko, The Illuminators of the Menologium of Basil II, DOP 16 (1962), p. 273-274, n. 97.

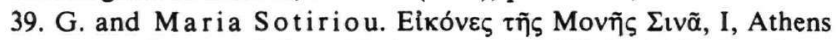
1956 (hereafter: Sot i ri o u, Eỉkóveৎ), pls 136-143, 146-150; II, Athens 1958, p. 121-123, 125-130. K. We it z m a n n, Byzantine Miniature and Icon Painting in the Eleventh Century, in: Studies (see note 6), p. 297-303, figs 301-303.

40. Doula Mouriki, La présence géorgienne au Sinaï d'après le témoignage des icônes du monastère de Sainte-Catherine, in: Buל̧á-

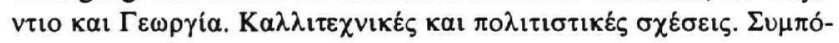
бto, Athens 1991, p. 39-40.

41. For the text of the inscriptions I am basing myself on the book of Sotiriou, as it was not possible to acquire photographs from the monastery at Sinai. 


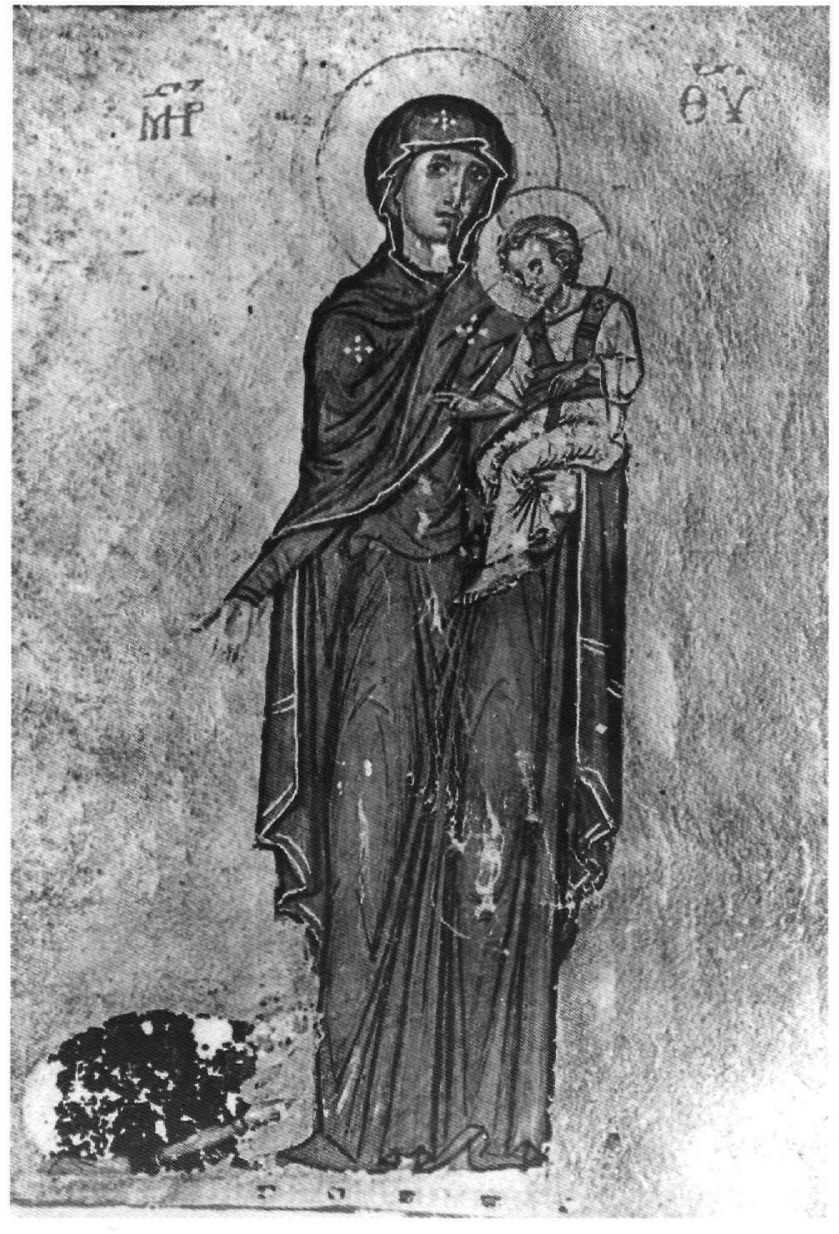

Fig. 8. Athos, Dionysiou 65, f. 12v. The Virgin and the monk Sabas, donor, scribe and painter.

the second inscription on the same panel Ioannes, the painter, having illustrated the miracles of Christ and His

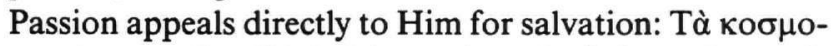

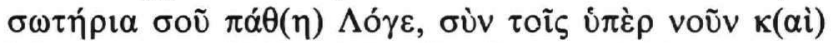

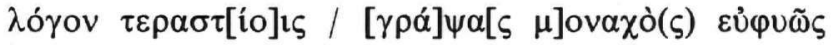

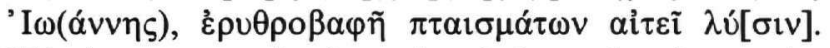
"Having appropriately painted in red colours thy world-redeeming Passion, o Word, together with thy miracles, surpassing mind and speech, Ioannes, the monk, asks for.forgiveness for his sins".

In the last Greek inscription on the back of the other main panel, depicting the Last Judgement, Ioannes the painter addresses his supplication for mercy directly to

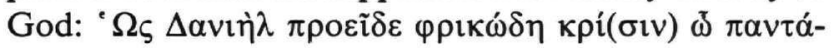

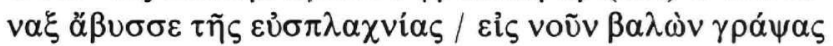

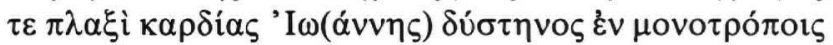

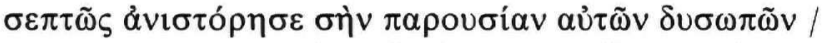

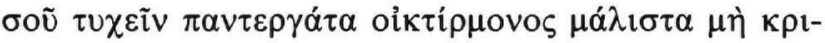

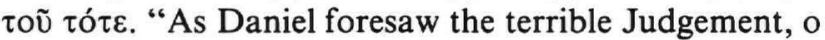
all-ruling abyss of mercy, having put in mind and written on the plates of the heart, Ioannes, unfortunate among monks, has respectfully painted thy Last Judgement imploring to have thee, creator of all, then merciful and not as judge".

In addition, a Georgian inscription on the front of the same panel includes a prayer addressed to Christ by the hieromonk Ioannes Tsohabi, whom Doula Mouriki identified with the Ioannes of the Greek inscriptions ${ }^{42}$. The context of the numerous inscriptions leaves no doubt that Ioannes Tsohabi, a Georgian hieromonk and a man of high education, was at the same time donor and painter of the icon and probably also the author of the epigrams. Moreover this ambitious patron and painter, who succeeded in including in his oeuvre all the saints and the Virgin as intercessors for his salvation, painted his self-portrait twice on the main leaves: once in prostration at the feet of the enthroned Virgin on the panel with the Christological scenes and the images of the Virgin (Fig. 9), and a second time kneeling in front of the gate of Paradise on the lower part of the panel depicting the Last Judgement.

The example of Ioannes Tsohabi, ktetor and painter of the hexaptychon of Sinai, is not isolated. Two wellknown icons representing Elijah and Moses ${ }^{43}$ in the same monastery, dated to the beginning of the 13th century, bear inscriptions which indicate, through their phraseology, that the donor Stephanos, who asks for forgiveness, was also the painter of the icons. The beautiful classicizing style of the icons and the scholarly epigrams, which are also translated in Arabic, document not only Stephanos' expertise as a painter but also his wide erudition.

A similar example of a painter who must have also been donor is found in a group of three icons at Sinai ${ }^{44}$ dated to the third decade of the 13th century ${ }^{45}$, all of which

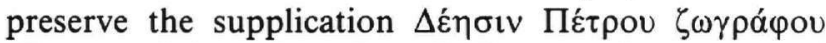
"Prayer of the painter Peter". The prominent place of the inscriptions and the introductory formula $\delta \varepsilon \dot{\eta} \sigma 1 \zeta$, usually applied to indicate patronage, led Doula Mouriki, who studied this group of icons, to assume that the painter Peter, probably a monk, was also the patron of the three icons bearing his name ${ }^{46}$.

A further example of an icon-painter and ktetor, that of the deacon and referendarios Ioannes, is documented in an inscription on the rear of the icon of Saint George at Struga dated to the year $1267^{47}$.

Considering Byzantine concepts about painters, it is surprising and particularly interesting to read Niko- 


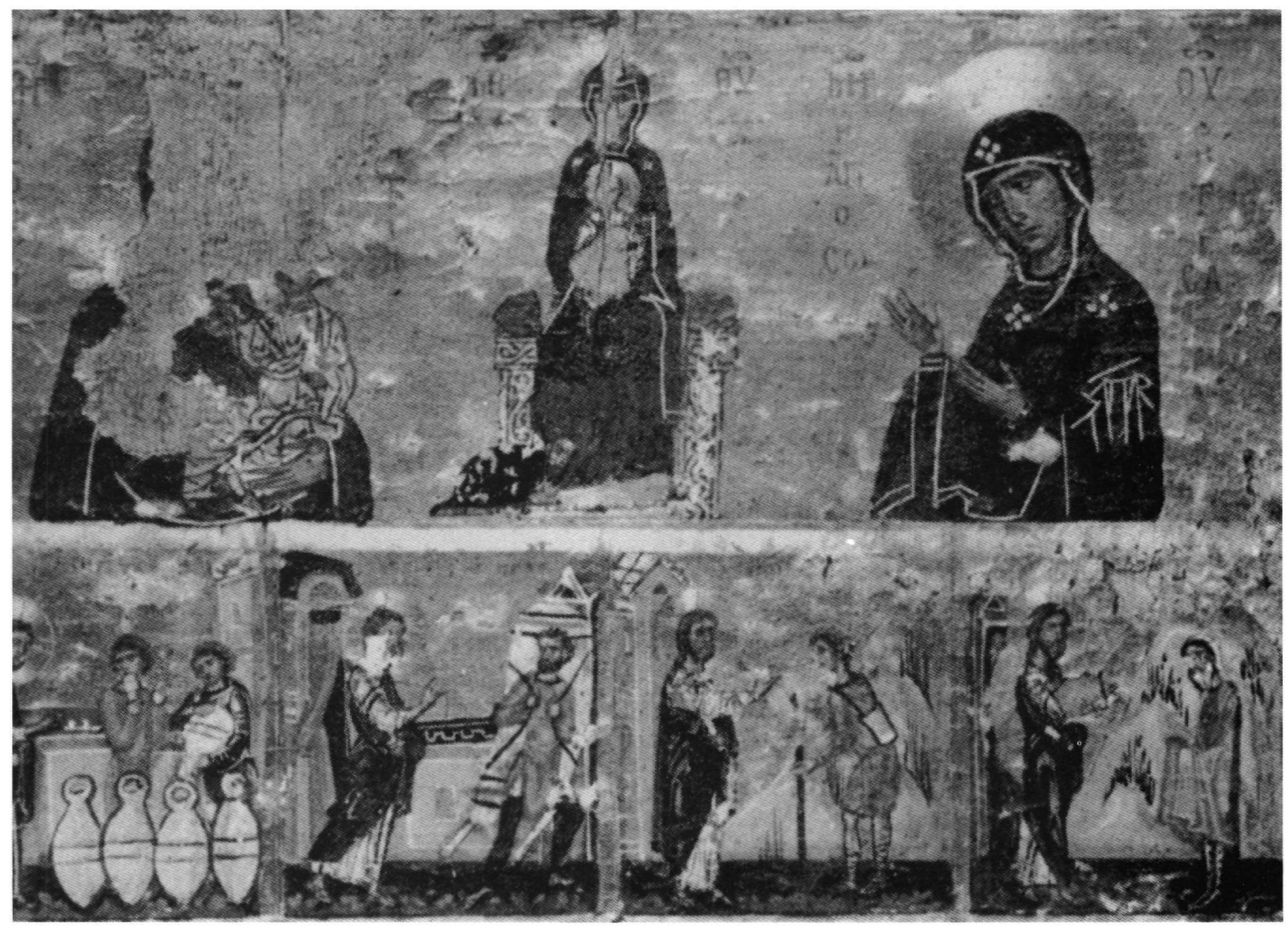

Fig. 9. Sinai, Monastery of Saint Catherine, Hexaptychon, detail. The monk Ioannes Tsohabi, donor and painter, kneeling in front of the Virgin.

42. Mouriki, La présence, op.cit., p. 39.

43. Sotiriou, Eikóves, I, pls 74-75; II, p. 88-90. Weitzmann, The Classical in Byzantine Art, in: Byzantine Art - An European Art (see note 6), p. 172ff., figs 135-136, and id., Studies, p. 172ff., figs 155-156. Id., Byzantium and the West Around the Year 1200, in: The Year 1200: A Symposium, The Metropolitan Museum of Art, New York 1975 , p. 63f., figs $25,26,37$. Id., Icon Programs of the 12th and 13th Centuries at Sinai, $\triangle$ XAE $\Delta^{\prime}$, IB' (1984), p. 102f., figs 31-32. La zarev, op.cit. (see note 31), p. 205, fig. 332. Id., Istorija Vizantijskoj živopisi, Moscow 1986, I, p. 98; II, fig. 332. Doula Mouriki, Eỉkó-

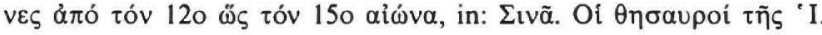

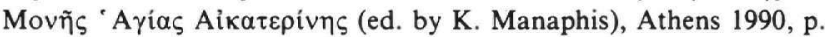
110 , fig. 34.

44. Sotiriou, Eỉkóvec, I, pls 155-156, 158; II, p. 135-137, 138-139. Doula Mouriki, Four Thirteenth-Century Sinai Icons by the Painter Peter, in: Studenica et l'art byzantin autour de l'année 1200 (1986), Belgrade 1988, p. 329-347. E a d., op.cit. (see note 43), p. 113f., figs 45, $47,48$.

45. The date is based on the portrait, depicted on one of them, of the
Patriarch Euthymios II of Jerusalem, who died at Sinai in the year 1224

46. Mouriki, Four Thirteenth-Century Sinai Icons, op.cit., p. $344 f$. On the contrary, small-scale figures, usually depicted kneeling in several icons at Sinai, which Sotiriou (Eikóves, I, pls 32, 159, 164, $168-170,221$; II, p. 45-46, 139, 143-144, 152-157, 194-195) thought might represent the painters, should rather be identified, as far as our present knowledge allows us to assume, with the donors of the icons. Cf. Mouriki, op.cit. (see note 43), p. 116, 125, figs 52, 76. E ad., A Pair of Early 13th-Century Moses Icons at Sinai with the Scenes of the Burning Bush and the Receiving of the Law, $\triangle$ XAE $\Delta^{\prime}$, I $\Sigma T^{\prime}$ (199192), p. 184.

47. V. J. D ju ri ć, Icônes de Jougoslavie, Belgrade 1961, p. 18-19, 84, no. 3, pl. III. P. Miljković-Pepek, L'icône de Saint Georges de Struga. Oeuvre du peintre Jean, CahArch 19 (1969), p. 213-221. K. Balabanov, Ikone iz Makedonije, Skopje 1969, p. XIV, XLII, pl. 10, 12. Gordan a Babić, Icônes, Paris 1980 , no. 9. On the inscription see F. Barišić, Dva grčka natpisa iz Manastira i Struge, ZRVI 8/2 (1964), Mélanges G. Ostrogorsky, II, p. 13-31. 
laos Mesarites' reference, in his Description of the Holy Apostles (Chapter 28), to the self-portrait of the mosaicist in the scene of the Holy Women at the

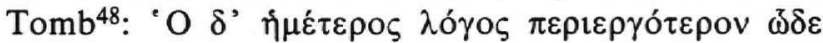

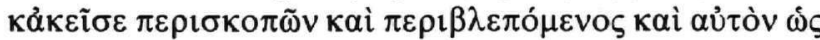

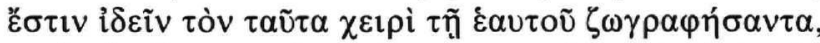

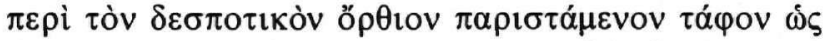

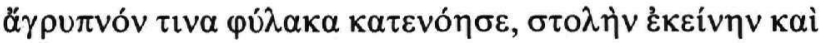

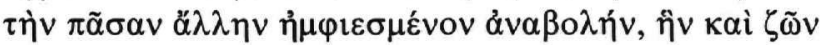

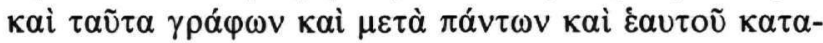

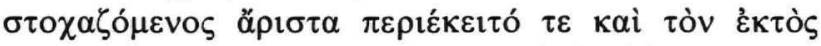

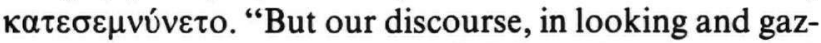
ing round curiously hither and thither, has recognized the man who with his own hand has depicted these things, as he may be seen standing upright by the Lord's tomb like a watchful guard, dressed in the same robe and other garments which he wore to adorn his outer appearance when he was living and painting these things and succeeding admirably [in the representation] both of himself and of all the other [particulars]"49.

It is evident from the above passage, that the painter, or rather the mosaicist, is not named in the text of Mesarites. Nevertheless, Heisenberg was able to decipher the name "Eulalios" in a marginal note added by the copyist ${ }^{50}$. Heisenberg believed that Eulalios lived in the 6th century, at the time of Justin II (565-578) ${ }^{51}$, but Bees and later Malickij convincingly showed that he lived in the 12th century, a view nowadays widely accepted ${ }^{52}$.

Eulalios' self-portrait in the church of the Holy Apostles is quite unique ${ }^{53}$, by Byzantine standards, and indicative of the special eminence he enjoyed in his and in later times. Eulalios is one of the very few Byzantine painters repeatedly mentioned in the written sources from the 12 th century onwards and, moreover, compared to ancient artists. His name is recorded in two poems of Theodore Prodromos ${ }^{54}$, in two epigrams of Nikephoros Kallistos Xanthopoulos ${ }^{55}$ as well as in Theodore Metochites' Logos 10 along with famous ancient sculptors and painters, such as Pheidias, Polygnotos, Zeuxis and Lysippos ${ }^{56}$.

Of particular interest is the combination of the Renaissance-like concept of a figure bearing the painter's features included in a biblical scene, with the medieval idea of suppressing the name of the artist ${ }^{57}$, which, as mentioned above, was only added on the margin by the scribe. This approach may be understood in the spirit of a prominence of ancient principles ${ }^{58}$ traceable also in the twelfth-century architecture ${ }^{59}$ and monumental painting $^{60}$ of Byzantium. It may, furthermore, be considered as indicative of the social conditions of the late 12th century ${ }^{61}$ when an emergence of the craftsmen from their anonymity has been observed ${ }^{62}$. A parallel phe-

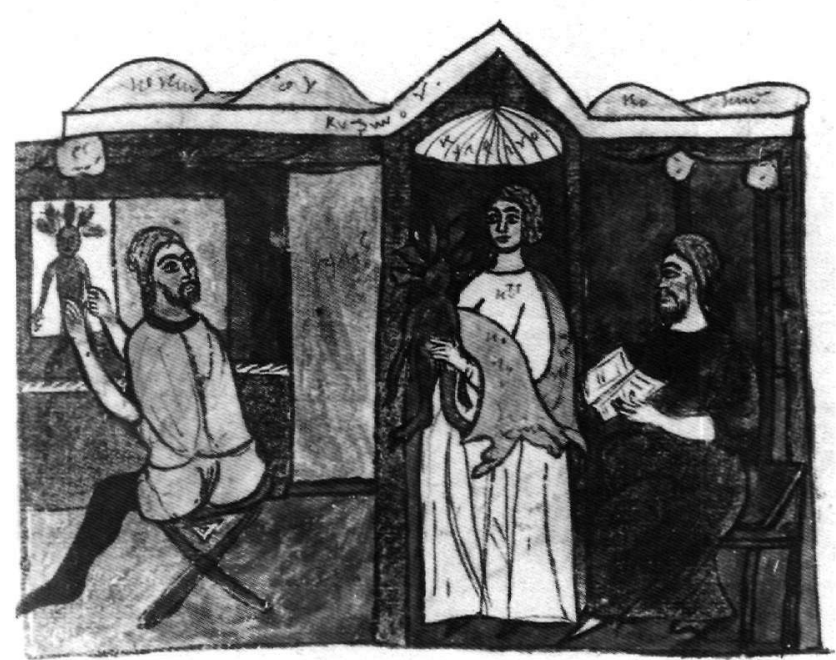

Fig. 10. Bologna, Biblioteca Universitaria, cod. 3632, f. 425v. Dioscorides, Sophia and the painter.

nomenon of individualism, concerning art production, also resulting from the political and socio-economic conditions of the time, is the broadening of the social range of patronage. In other words, alongside representatives of the imperial administration and members of the ruling dynasty, laymen of local eminence are also recorded as church donors in the second half of the 12th century, as for example in Kastoria ${ }^{63}$ and in Andros ${ }^{64}$. These social developments, echoed in Late Comnenian

48. A. Heisenberg, Grabeskirche und Apostelkirche, Zwei Basiliken Konstantins, Leipzig 1908, II, p. 63-64, pl. II. G. Downey, Nikolaos Mesarites: Description of the Church of the Holy Apostles at Constantinople, TAPS N.S. 47/6 (1957), p. 855-924, esp. 884, 910. O. Demus, "The Sleepless Watcher", JÖB 28 (1979), p. 241-245, thinks that Mesarites mistakenly interpreted the man's figure in the scene of the Holy Women as the artist's portrait and suggests an identification of this figure with the prophet David. The subject has been recently discussed by Theonie Baseu-Barabas, Zwischen Wort und Bild: Nikolaos Mesarites und seine Beschreibung des Mosaikschmucks der Apostelkirche in Konstantinopel (Ende 12. Jh.) (Dissertationen der Universität Wien 230), Vienna 1992, p. 208-209.

49. Translated by C. Mango, The Art of the Byzantine Empire 3121453, Englewood Cliffs, p. 233, § 23.

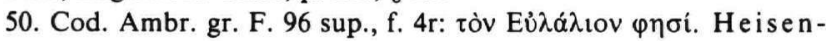
be rg, op.cit., II, p. 63, 170-171, pl. II. Downe y, op.cit., p. 860, 884, 910.

51. Heise nberg, op.cit., II, p. 166ff. Id., Die alten Mosaiken der Apostelkirche und der Hagia Sophia, in: छévı $\alpha$ Hommage International à l'Université Nationale de Grèce, Athens 1912, p. 121-142, esp. 138-139. Id., Die Zeit des byzantinischen Malers Eulalios, PhW 41 (1921), cols. 1024-1032. Cf. B a se u-B a ra ba s, op.cit., p. 228, n. 642. 52. N. A. Bees (B⿱亠幺十 $\eta$ ), Kunstgeschichtliche Untersuchungen über die Eulalios-Frage und den Mosaikschmuck der Apostelkirche zu Konstantinodel. Separatabdruck aus Renertorium für Kunstwissen- 
schaft XXXIX, Berlin 1917, p. 1-62. H. Ma li ckij, Remarques sur la date des mosaïques de l'église des Saints-Apôtres à Constantinople décrites par Mesaritès, Byzantion 3 (1926), p. 123-151. For a critical discussion of the older bibliography see Baseu-Barabas, op.cit., p. 228-231. On the date of the redecoration of the Holy Apostles, without any reference to Eulalios though, see Anne Wharton Epstein, The Rebuilding and Redecoration of the Holy Apostles in Constantinople: A Reconsideration, GRBS 23 (1982), p. 9-92.

53. Evidently based on the example of Eulalios, A. Xyngopoulos,

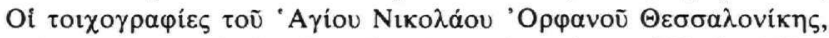
Athens 1964 , p. 13, fig. 12, believed that the painter of Hagios Nikolaos Orphanos in Thessalonica depicted his own features in the figure of the stable-boy who holds the horses in the scene of the Adoration of

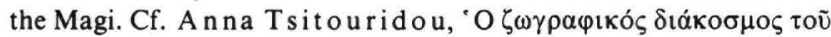

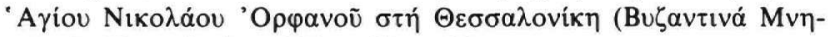
$\mu \varepsilon i \alpha$ 6), Thessalonica 1986, p. 88, n. 38.

54. E. Miller, Poésies inédites de Théodore Prodrome, Annuaire de l'Association pour l'encouragement des études grecques 17 (1883), p. 33. A. Maiuri, Una nuova poesia di Teodoro Prodromo in greco volgare, BZ 23 (1914-1919), p. 397-407, esp. 400, I.43.

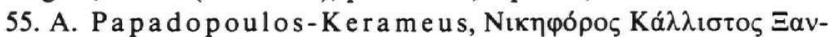

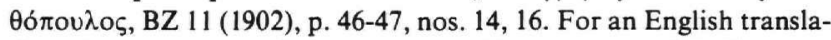
tion of the above-mentioned passages of Prodromos and Kallistos see Mango, op.cit. (see note 49), p. $230 \mathrm{ff}$.

56. F. 211v, Ševčenko, Theodore Metochites, op.cit. (see note 1), p. 50-51, n. 227. References to ancient artists - Apelles, Lysippos, Parrhasios, Pheidias, Praxiteles, Zeuxis - were a literary locus communis for Byzantine authors, ibid., p. 51, n. 227, 229 (Photius, Constantine Manasses, Theodore Prodromos); C. M ango, Antique Statuary and the Byzantine Beholder, DOP 17 (1963), p. 65-66 (Photius, Theophanes Continuatus, Nicephorus Chumnos). Cf. Anna Comnena, Alexias III, 2, CSHB, Bonn 1839, p. 140, I.10-11.

57. An interesting parallel is found in Photius, Homily 10, $\S 5$ on the church of Theotokos of the Pharos. Photius refers to the celebrated ancient masters Pheidias, Parrhasios, Praxiteles and Zeuxis, but finds their work inferior to that of the ninth-century mosaicist of the church of the Theotokos. Nevertheless, he passes over in silence the name of his contemporary artisans, C. A. Mango, The Homilies of Photius, Patriarch of Constantinople, (DOS III), Washington, D.C. 1958, p. 1987; id., op.cit. (see note 49), p. 186.

58. According to a disputed ancient tradition of which Mesarites must have been aware, Pheidias inserted his own features as well as those of Pericles when carving two figures of the Amazonomachy on the shield of the statue of Athena in the Parthenon, Plutarch, Bíor

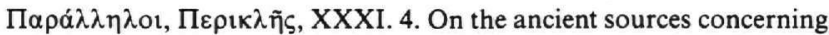
this subject and their critical interpretation see F. Preiß h of en, Phidias-Daedalus auf dem Schild der Athena Parthenos? Ampelius 8, 10, JdI 89 (1974), p. 50-69. On self-portraits of ancient artists see $\mathrm{Han} \mathrm{na}$ Philipp, Tektonon Daidala, Berlin 1968, p. $113 \mathrm{ff}$. I wish to thank my colleague and friend Georgia Kokkorou-Alevras for this note.

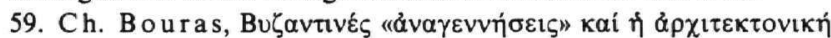

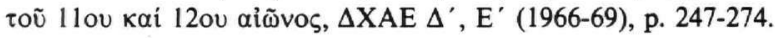

60. Doula Mouriki, Stylistic Trends in Monumental Painting of Greece during the Eleventh and Twelfth Centuries, DOP 34-35 (1982), p. 77-124, esp. $111 \mathrm{ff}$. Maria Panayotidi, The Wallpaintings in the Church of the Virgin Kosmosoteira at Ferai (Vira) and Stylistic Trends in 12th Century Painting, First International Symposium for Thracian Studies "Byzantine Thrace", Image and Character, Komotini 1987 = ByzF XIV (1989), p. 459ff.

61. On the socio-economic developments of the time N. Svoronos,

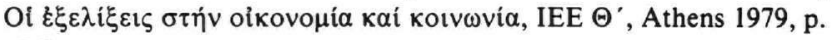
$67 \mathrm{ff}$.
62. Cf. Mango, op.cit. (see note 49), p. 230. Two other painters or mosaicists are known from the same period: Ephraim, documented in two inscriptions - in Latin and in Greek - of the year 1169 in the church of the Nativity in Bethlehem, G. Kühnel, Wall Painting in the Latin Kingdom of Jerusalem, Berlin 1988, p. 4-5, and Theodore Apseudes, who signed his name in the Enkleistra of Saint Neophytos near Paphos in Cyprus in the year 1183, C. Mango - E. J. W. $\mathrm{H}$ a w kins, The Hermitage of St. Neophytos and its Wall-paintings, DOP 20 (1966), p. 182-183, figs 101-102.

63. Svetlana Tomeković-Reggiani, Portraits et structures sociales au XIIe siècle. Un aspect du problème: Le portrait laïque, Actes du XVe Congrès International d'études byzantines, Athènes 1976, II B,

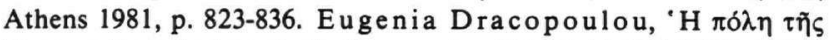

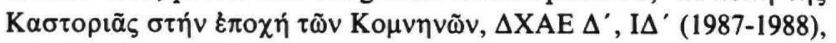
p. $307-314$, esp. 312 .

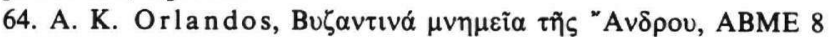
(1955-56), p. 28. Laskarin a Bouras, Architectural Sculptures of the Twelfth and the Early Thirteenth Centuries in Greece, $\triangle$ XAE $\Delta^{\prime}$, $\Theta^{\prime}$ (1977-79), p. 65. Myrtali Acheimastou-Potamianou,

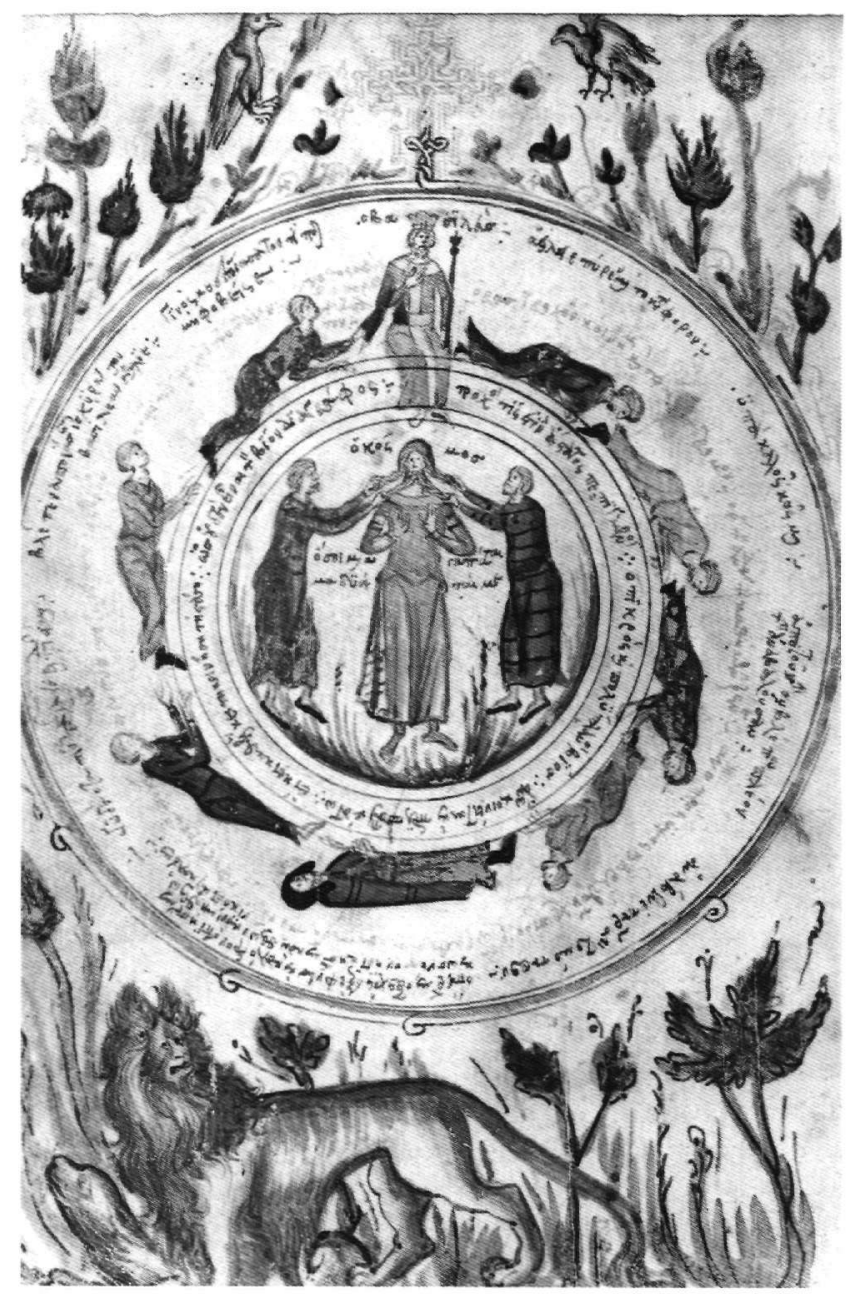

Fig. 11. Paris, Bibliothèque Nationale, Par. gr. 36, f. 163v. The painter-monk Nicodemus in the Wheel of Life. 
art, are increasingly continued in Late Byzantine times and strengthened by the historical conditions created by the Fourth Crusade. In this late period of Byzantine history, the epigraphic evidence shows that painters' names - less in dedicatory inscriptions and more in the form of "signatures" or short invocations - are more and more frequently mentioned ${ }^{65}$. Moreover, information from documents also indicates a certain rise in the social status of painters, especially in large urban centres like Thessalonica ${ }^{66}$. Parallely, western European art, in the same Late Medieval period, shows an increasing number of images of painters at work ${ }^{67}$. Has the rise in the social position of painters in Late Byzantine society entailed any personal involvement of the painter in the formation of the church programme? To answer this question, a thorough and overall investigation of the monuments is needed which is beyond the aims of the present paper. For the time being, we will limit ourselves to an observation concerning the church of $\mathrm{Pa}$ nagia Peribleptos in Ochrid (1294/95). According to Grozdanov, the representation of two otherwise rarely depicted prelates on the north wall of the bema of the Peribleptos - namely Saint Michael the Confessor, bishop of Synnada in Phrygia ( $\dagger 821)$ and Saint Eutychios, patriarch of Constantinople ( $\dagger 582$ ) - may be attributed to the personal wish and intervention of the celebrated painters Michael and Eutychios ${ }^{68}$ who have, furthermore, tried to make their personality present by writing their names in several places in the church ${ }^{69}$. Nevertheless, it is interesting to note that, as in previous periods, there are no representations of painters in Byzantine monumental art and that former theories in this respect are no longer accepted ${ }^{70}$. Radojčić, in his time, identified as painters a group of persons, wearing long white garments and high cylindrical white headcovers, in the scene of John Chrysostom as "Fountain of Wisdom" in the narthex of Lesnovo (1349) $)^{71}$. Furthermore, he interpreted the passage written on Chrysostom's scroll, which constitutes the beginning of his homily on the 50th psalm ${ }^{72}$ and reads Oi $\zeta \omega / \gamma \rho \alpha \dot{\varphi} \varphi \mathrm{or} / \mu \iota \mathrm{o}$ ov / $\tau \varepsilon \tau \eta$ $\tau \varepsilon / \chi \nu \eta \tau \eta \nu / \varphi v ́ \sigma ı v / \kappa(\alpha i) \kappa \varepsilon \rho \alpha / v u v / \tau \varepsilon$, as an appeal to the painters to "imitate nature through their art and temper it through mixture". Radojčić, therefore, conceived the whole scene as a symbolic representation of the moderate stylistic trend applied in the narthex of Lesnovo.

However, recent research has shown that the group with the characteristic cylindrical hats (skaranika) thought to represent painters, actually depicts priests ${ }^{73}$. Moreover, if we read the complete passage of Chrysostom's Homily it is clear that the author uses the idea of painters, as church fathers often do, to make a simile between

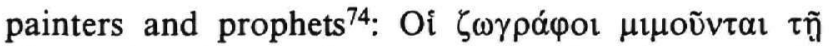

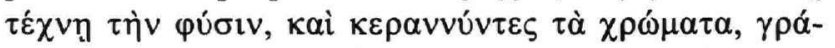

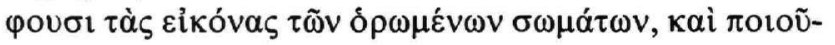

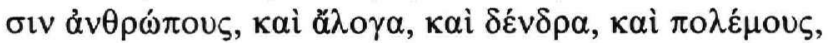

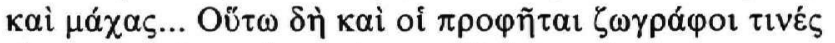

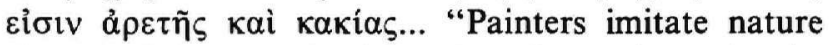
through their art and, mixing the colours, they paint the pictures of the visible bodies, and make (paint) men and non-reasoning beings and trees and wars and battles... So prophets are painters of virtue and evil...".

Rare effigies of painters are included in Late Byzantine manuscripts. A 15th-century copy of the codex of Dioscorides of Anicia, now in Bologna (Biblioteca Universitaria cod. 3632) ${ }^{75}$, comprises on f. $425 \mathrm{v}$ (Fig. 10) an illumination copying that of $\mathrm{f} .5 \mathrm{v}$ of the Vienna Dioscorides (Fig. 1). One or more intermediate codices, now lost, may have existed. The personification of Epinoia, named here Sophia, holds the mandragora which is depicted in huge dimensions, obviously resembling a creature and not the root of the plant. The bench with the painter's implements is missing and the painter, who does not hold a brush, seems to mould rather than to paint the human-shaped mandragora which is much larger than the parchment leaf on which it should be depicted. The board of the easel is not fixed on a tripod. The misunderstanding is continued in the marginal in-

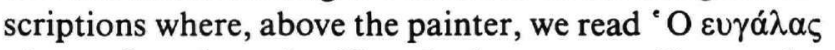
$\tau o ̀ v \mu \alpha v \delta \rho \alpha \gamma o ́ \rho \alpha v$, i.e. "he who has uprooted", not who has painted, "the mandragora". It is more than evident that the figure of the painter from Late Antiquity has completely lost its meaning.

Of a quite different character is the self-portrait of the painter in the codex Par. gr. 36 in the National Library of Paris, dated to the end of the 14th or the beginning of the 15 th century ${ }^{76}$. Among the figures depicted around the Wheel of Life on f. 163v (Fig. 11), a monk is represented lying in its lower part. The accompanying inscription reads: $\mathrm{E} \pi \varepsilon \iota \rho(\varepsilon v) \mu \varepsilon$ o $\tau \rho \circ \chi$ ò $\varsigma \varepsilon \xi \hat{\varepsilon} \varphi v \eta \varsigma \kappa(\alpha i)$

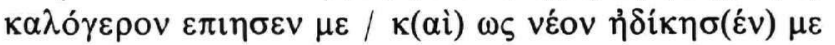

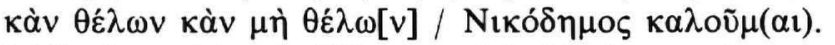
"All of a sudden the Wheel took hold of me and made me a monk and did injustice to me, the young man, whether I wanted it or not. Nicodemus is my name". Another inscription of $f .203 \mathrm{v}$ consisting of four dodecasyllabic verses written in a scholarly style informs us that the painter is the famous Nicodemus, of celebrated birth. It reads, according to Xyngopoulos' transcrip-

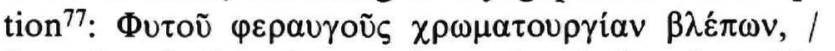

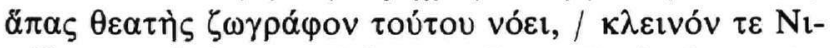

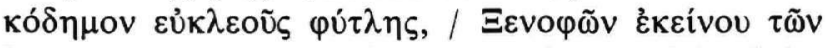

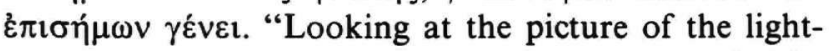
bringing plant, every speciator would bring to mind its 
painter, the famous Nicodemus, of celebrated birth, a descendant of the noble lineage of Xenophon".

Xyngopoulos identifies the painter Nicodemus, mentioned on f. $203 \mathrm{v}$, with the monk Nicodemus depicted under the Wheel of Life on f. 163v (Fig. 10). If we accept this identification, which seems very reasonable, then we have here a Late-Byzantine painter's self-portrait. Its context differs, though, from the examples previously examined. Nicodemus is not depicted as a humble servant of God. The lofty self-characterizations in the epigram of f. $203 \mathrm{v}$ and the iconographic context of the miniature comprising his self-portrait on $f .163 \mathrm{v}$ are alien to Byzantine concepts. They demonstrate a strong individualism, revealing a new approach, which can be associated with the social changes of the period of transition from the Middle Ages to the Renaissance ${ }^{78}$. Parallely, representations of Saint Luke painting the icon of the Virgin become more frequent in the Late Byzantine period, for example in Mateić ${ }^{79}(1356-60)$, in a Lectionary of the monastery of Saint John on Patmos ${ }^{80}$ (MS. 330, f. 82v) of the year 1427 and in Cod. gr. 233 (f. $87 \mathrm{v}$ ) of the monastery of Saint Catherine at Sinai ${ }^{81}$ of the 15 th century, also indicating the growing emphasis on the personality of the painters in the last phase of the Middle Ages.

To sum up, the rarity of references by name to Byzantine painters in the written sources and in church inscriptions has its parallel in the scarcity of their portraits in Byzantine art. The painter's image in the Early Christian codex of Dioscorides in Vienna attests to the continuity of the tradition of Late Antiquity. The majority of extant effigies belong to the period extending from the

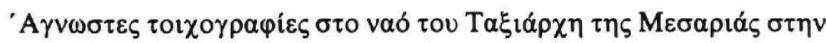

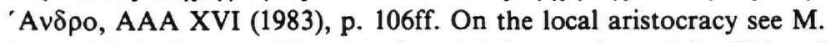
Angold, Archons and Dynasts: Local Aristocracies and the Cities of the Later Byzantine Empire, The Byzantine Aristocracy. IX to XIII Centuries, ed. by M. Angold (BAR International Series 221), Oxford 1984, p. 236-253.

65. Kalopissi-Verti, Painters in Late Byzantine Society, op.cit. (see note 3).

66. Ibid., p. 11ff. For the economic and social transformations in the cities in the Late Byzantine period see N. Oikonomidès, Hommes d'affaires grecs et latins à Constantinople (XIIIe-XVe siècles). (Conférence Albert-Le-Grand 1977), Montreal-Paris 1979, esp. p. $114 \mathrm{ff}$. For the role of the aristocracy in relation to artistic activities in the

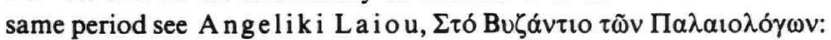

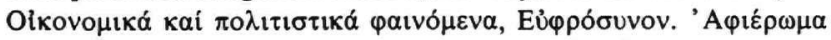

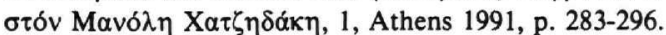

67. V. W. Egbert, The Mediaeval Artist at Work, Princeton 1967.
A. Martindale, The Rise of the Artist in the Middle Ages and Early Renaissance, London 1972. P. B inski, Medieval Craftsmen. Painters, London 1991.

68. Cv. Grozda nov, Ohridske Beleške Sv. Mihailo i sv. Eutihije u crkvi sv. Bogorodice Perivlepte, Zograf 3 (1969), p. 11-12.

69. P. Miljković-Pepek, Deloto na zografite Mihailo i Eutihij, Skopje 1967 , p. $18 \mathrm{ff}$.

70. About the White Church of Karan (1340-42) where the presbyter Georgije Medoš, depicted in the apse, was previously thought to represent the master of the church decoration, a view no longer accepted, see Sv. Radojčić, Staro srpsko slikarstvo, Belgrade 1966, p. 142-143; V. D ju rić, Byzantinische Fresken in Jugoslawien, Belgrade 1976 , p. $89-90,271$, n. 71.

71. Sv. Radojčić, Die Entstehung der Malerei der paläologischen Renaissance, JÖBG 7 (1958), p. 116, fig. 2. I d., Zografi, o teoriji slike i slikarskog stvaranja u našoj staroj umetnosti, Zograf 1 (1966), p. 14, n. 55, fig. on p. 13. Id., Geschichte der serbischen Kunst, Berlin 1969, p. 81. I d., Lesnovo, Belgrade 1971, p. XI, fig. 43. On the iconographic subject of the "Fountain of Wisdom" see Tania Velmans, L'iconographie de la "Fontaine de Vie", la tradition byzantine à la fin du moyen âge, Synthronon, Paris 1968, p. $119-128$ and recently V. Djurić, Les docteurs de l'église, Eủppóouvov (see note 66), 1, p. $131 \mathrm{ff}$, pl. 67.

72. PG 55, col. $565 \alpha^{\prime}$ ff.

73. N. K. Moran, Singers in Late Byzantine and Slavonic Painting, Leiden 1986, esp. p. 37, 68, pl. 32. Figures with the same dress and head covering are depicted in all four pendentives of the dome in the narthex of Lesnovo, M. N. L. O ku nev, Lesnovo, in: L'art byzantin chez les Slaves, Premier recueil dédié à la mémoire de Th. Uspenskij, Paris 1930, p. 236-237, pl. XXXIII. G. Millet - Tania Velmans, La peinture du moyen âge en Yougoslavie, IV, Paris 1969, figs 38-40; Mora n, op.cit., p. 68-69, pls 33-35.

74. PG 55, col. $565 \alpha^{\prime}$.

75. P. Capparoni, Intorno ad una copia delle scene raffiguranti l'estrazione della mandragora, che ornavano il Codice cosi detto " $\mathrm{Di}$ oscoride di Juliana Anicia" da lungo tempo scomparse, Atti del V Congresso Internazionale di Studi Bizantini, Roma 1936, II = SBN 6 (1940), p. 63-69.

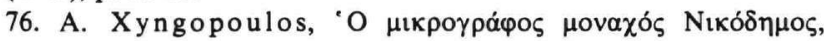

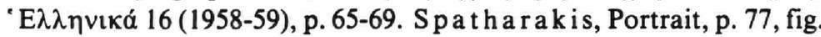
44. Xyngopoulos had prepared a study on the full-page miniatures of the codex which he never published, cf. A. Xyngopoulos, Fortitudo, Zograf 10 (1979), p. 92-93, n. 2.

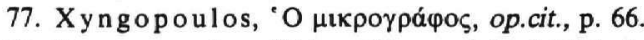

78. X yng op oul os, ibid., p. 69 , was right, I think, in attributing the production of the manuscript in a Latin-occupied region of Byzantium.

79. R. Ha man n-MacLe a n, Grundlegung zu einer Geschichte der mittelalterlichen Monumentalmalerei in Serbien und Makedonien (Marburger Abhandlungen zur Geschichte und Kultur Osteuropas 4), Gießen 1976, drawing on p. 107.

80. Spatharakis, Corpus, I, p. 69 , no. 287 ; II, fig. 508 .

81. H. Belting, Bild und Kult, Munich 1991, p. 64f., fig. 14, cf. p. 70-72. The number of pictures of Saint Luke portraying the Virgin rises sharply in the post-Byzantine period, Theano $\mathrm{Ch}$ atzidaki,

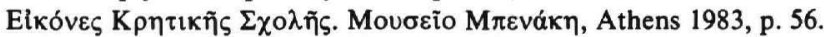
Ead., in: El Greco of Crete, Exhibition on the Occasion of the 450th Anniversary of his Birth, ed. by N. Hadjinicolaou, Herakleion 1990, p. 118-123, 316-319. Maria Constantoudaki-Kitromilidis,

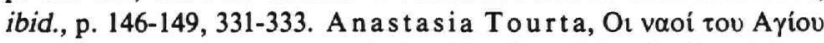

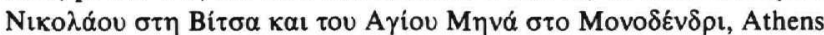
1991, p. 138-139. 
first half of the 9th to the end of the 12th century and include a) two anonymous and abstract images of painters at work used to illustrate metaphors in theological texts, as in the codices Par. gr. 923 and Dionysiou 61; b) a unique effigy of an anonymous but real painter, if the tiny kneeling figure on $\mathrm{f} .2 \mathrm{v}$ of Coislin 79 is rightly interpreted; c) a group of examples in manuscripts (Melbourne 710/5 and Dionysiou 65) and icons (Hexaptychon of Ioannes Tsohabi at Sinai) where the eponymous painters are portrayed in their capacity as donors. These last examples attest to the existence of monk-painters who were not mere craftsmen but men of learning, disposing of certain financial means, who combined the capacities of donor, scribe and painter and possibly also author of the accompanying epigrams. There are no extant examples of painters' effigies in monumental painting. The unique recorded statement of Nikolaos Mesarites, in his Description of the Holy Apostles, that his almost contemporary mosaicist - whose name, Eulalios, has been added on the margin by the copyist - had his own features painted in a secondary figure of a Christological scene, surprising as it may seem at first, should be understood in the spirit of a revival of ancient art principles, also evident in the architecture and painting of the 12th century, and is in conformity with the social changes of the time.

Very few painters' self-portraits are known from the Late Byzantine period, although one would expect a greater number of examples, as the historical conditions and socio-economic transformations after the Fourth Crusade favoured, to some degree, a rise of the status and personality of craftsmen. The image of the illuminator comprised in the fifteenth-century codex of Dioscorides in Bologna (Bibl. Univ. cod. 3632) shows many misinterpretations in comparison to its Early Christian model, the Dioscorides of Vienna, probably due to the intermediate copies. On the contrary, the effigy of the eponymous painter in the codex Par. gr. 36 (end of 14 th/beginning of 15 th century) shows a completely different iconographic approach in comparison with the examples of the previous period and indicates an individualism consonant with the historical events and social alterations of this period of transition from the Middle Ages to the Renaissance.

\section{ACKNOWLEDGEMENTS}

For useful discussions on the subject I wish to thank my friends and colleagues Mary Aspra-Vardavaki, Angeliki Mitsani and Zaza Schirtladze. My acknowledgements are due to the following museums and libraries which provided photographs and permission to reproduce them: Athens, Benaki Museum for Fig. 4; Bologna, Biblioteca Universitaria for Fig. 10; Melbourne, National Gallery of Victoria for Fig. 7; Paris, Bibliothèque Nationale for Figs 2, 5, 11; and Vienna, Österreichische Nationalbibliothek for Fig. 1. Figs 3 and 8 have been repro-

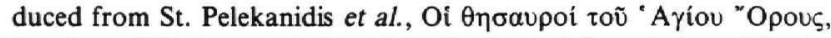
I, Athens 1973, by permission of the Patriarchal Foundation of Patristic Studies, and Fig. 9 from G. and Maria Sotiriou, Eỉkóvę $\tau \tilde{\eta} \varsigma$ Movĩ $\Sigma$ เıã, I, Athens 1956. 